The $2{ }^{\text {nd }}$ Conf. of SSFOP "Future of Ornamental Plants in Egypt and Arab World", Cairo, Egypt, 21/2/2016

Scientific J. Flowers \& Ornamental Plants

www.ssfop.com/journal

ISSN: 2356-7864

\title{
EFFECT OF MINERAL, BIO-FERTILIZATION AND GROWING MEDIA ON GROWTH, FLOWERING AND CORMS PRODUCTION OF GLADIOLUS GRANDIFLORUS CV."WHITE PROSPERITY" PLANT
}

\author{
M.R.A. Hassan ; A.H.M. El-Naggar ; M.N. Nasr ${ }^{* *}$ and M.B. El-Deeb ${ }^{* *}$ \\ * Floriculture, Ornamental Horticulture and Landscape Gardening Dept., Fac. Agric., (EL-Shatby), \\ Alexandria Univ. Egypt. \\ *** Ornamental Plants and Landscape Gardening Research Dept., Hort. Res. Inst., ARC, Alex. Egypt.
}

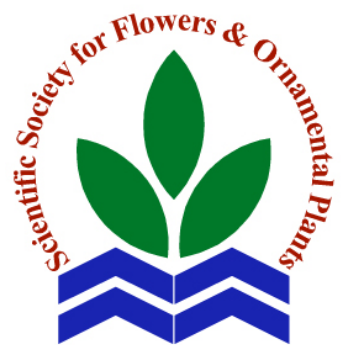

Scientific J. Flowers \& Ornamental Plants, 3(1):45-70 (2016).

Received $14 / 1 / 2016$

Revised by: Prof. Dr. A.Z. Sarhan, Cairo Univ.

Prof. Dr. B.M. Weheda, Hort. Res. Inst., ARC.

ABSTRACT: This work was carried out in the Nursery of Floriculture, Ornamental Horticulture and Landscape Gardening Department, Faculty of Agriculture, Alexandria University, during the two successive seasons of 2010 and 2011. The aim of the present investigation was to evaluate the effect of growing media, mineral, and bio-fertilization on growth, flowering and corm production on Gladiolus grandiflorus L. cv. "White Prosperity".

The experiment was a split-split plot design in three replicates, and forty-five treatments in each. The main plot represented the different growing media $\left(\mathrm{GM}_{1}\right)$ 100\% sandy soil, $\left(\mathrm{GM}_{2}\right)$ 100\% new reclaimed area (sandy-loam), $\left(\mathrm{GM}_{3}\right) 50 \%$ sand $+50 \%$ peatmoss, $\left(\mathrm{GM}_{4}\right) 50 \%$ sand $+50 \%$ New reclaimed area (sandy-loam) and $\left(\mathrm{GM}_{5}\right) 50 \%$ New reclaimed area (sandy-loam) $+50 \%$ peatmoss. The sub-plot was the mineral fertilization NPK (19:19:19) which was used at three levels $50 \%$ NPK of recommended doses, $75 \%$ NPK of recommended doses and $100 \% \mathrm{NPK}$ of recommended doses. The sub sub-plot represented bio-fertilizers [Nitrobine + Phosphorein $1: 1 \mathrm{w} / \mathrm{w}$ ] at rates $(0.0,5.0$ and $10.0 \mathrm{~g} /$ plant). The best treatment due to these combination was occurred at $\mathrm{GM}_{3}$ (50\% sand $+50 \%$ peatmoss) plus all levels of NPK combined with 5.0 and $10.0 \mathrm{~g}$ of biofertilizers/plant) on growth and flowering characteristics. $\mathrm{GM}_{5}$ (new reclaimed $50 \%+50 \%$ peatmoss) and $\mathrm{GM}_{3}(50 \%$ sand $+50 \%$ peatmoss $)+100 \%$ NPK $+10.0 \mathrm{~g} /$ plant Nitrobine + Phosphorein gave the best result on corms production (corm volume and number of cormlets/plant). The best treatment was $\left(\mathrm{GM}_{3}\right)+100 \%$ NPK combined with the doses of bio-fertilizers (5.0 or $10.0 \mathrm{~g} /$ plant) gave the best result in leaf chlorophyll ( $\mathrm{a}$ and $\mathrm{b}$ ).

Key words: Gladiolus, flowering bulbs, mineral fertilizer, biofertilizer, growing media.

\section{INTRODUCTION}

The commercial production of gladiolus are one of the most used flowers for florist cut flower arrangement due to its excellent keeping quality, wide range of forms, ability to withstand long distance transportation. Therefore, paying a great attention to improve both qualitative and quantitative characteristics of gladiolus.

Among the industry of floriculture, gladiolus occupies an important position as one of the most important and economic cut flower crops. Gladiolus is one of the flowering bulbs that grow from corms, it can 
be cultivated under Egyptian condition at any time, so that flowers of gladiolus are being available all over the year.

This widespread production may attribute to the short growth period that taken until flowering, in addition to the various colors, forms, and the high keeping quality of its flowers. Gladiolus is represented by 180 species belong to the family Iridaceae (Hogan, 1990).

Nutritional requirement is considered as a limiting factor for gladiolus plant growth and corms production. Nitrogen is an essential element in many important plant compounds such amino acid, enzymes, nucleic acid and chlorophyll also for carbohydrate use within plant.

Many investigators working on bulbous ornamentals reported that, mineral fertilizer NPK is very important to plant growth and development. It stimulated the growth, improved yield of flowers and flowering characteristics, and increased bulb yield and bulblets.

Since years ago, the use of bio-fertilizers was suggested to be a choice restores the natural conditions of safe and clean environment. Bio-fertilizers are preparations containing one or more of beneficial microorganisms that can release nutrients from rocks and organic matter in the soil to become available for plants.

Energy saving, environment conservation, and pollution control have been the most pronounced issue nowadays all over the world. Minimizing chemical fertilization usage, organic gardens, and biofertilization are now the new strategies in all agricultural domains around the world. Biofertilization is extremely beneficial to plant growth and ensures, if successful, neglecting, or at least, minimizing chemical fertilization and or its avoidance. It is also an economic way of fertilization. (Samira and El-Tayeb, 2008)

Recently, a great deal of interest has been directed to the incorporation of the nitrogen-fixing bacteria to the growing plants. It considered as an alternative and cheap way of fertilization, fertilizer conservation, and also chemical $\mathrm{N}$ fertilization avoidance. Inoculation of the host plants can results in various changes in plant growth parameters, which may or may not affect crop yield (Bashan and Levanony 1990). Although the principal mechanism by which the nitrogen fixing bacteria, Azospirillum, enhance plant growth is not fully elucidated, they proposed three different modes of actions. Azospirilla manifest their effects through atmospheric nitrogen fixation or hormonal effects on plants or improvement of root development; mineral uptake, and plant water relationships. Inoculation with Azospirillum species has been carried out almost exclusively on large variety of cereals (Partiquin et al., 1983).

Soil types and textures profoundly influence the growth and flowering of many bulbous ornamentals. Landscape gardeners have been mixing to the sandy soil, in the newly reclaimed areas, to improve and or to enhance its physical and chemical properties. Soil texture, as a growing media, could substantially affects growth of bulbeous ornamentals.

This work aims to determine the beneficial effects of chemical (NPK) and bio-fertilizers (nitrobein and phosphorein) on growth, flowering, corm productivity and chemical composition of gladiolus plants growing under different media.

\section{MATERIALS AND METHODS}

The present work was carried out during two successive seasons (2010 and 2011) at the nursery of the Department of Floriculture, Ornamental Horticulture and Landscape Gardening of Faculty of Agriculture, Alexandria University, Egypt during the successive seasons of 2010 and 2011 to investigate the effects of different levels of mineral , bio-fertilizers (Nitrobein + Phosphorein) and growing media on the growth, flowering and corms and cormels production of gladiolus plants. 
Corms of Gladiolus grandiflorus cv. "White Prosperity" 8-10 cm in circumference, were brought from private sector whose imported it from Holland for both seasons. The corms planting on $22^{\text {th }}$ April 2010 and $9^{\text {th }}$ November 2010 in pots of $20 \mathrm{~cm}$ diameter pack with the five chosen growing media in full sunny place on the first and second seasons, respectively.

\section{Treatments and Experimental layout:}

\section{Preparation of growing media:}

Five different soil types were used as growing media.

1- Sandy (100\%) $\left(\mathrm{GM}_{1}\right)$.

2- New Reclaimed Area (N.R.A.) (100\%) $\left(\mathrm{GM}_{2}\right)$.

3- Sandy + peatmoss (50+50\%) $\left(\mathrm{GM}_{3}\right)$.

4- Sand + New Reclaimed Area $(50+50 \%)\left(\mathrm{GM}_{4}\right)$.

5- Peatmoss + New Reclaimed Area $(50+50 \%)\left(\mathrm{GM}_{5}\right)$.

The last three soil textures were stimulated by mixing the first two types of soil together in the ratio of $(1: 1)$ (by volume). Each of the $20-\mathrm{cm}$ clay pots was filled with these different soil types. The mechanical analysis of the sandy soil used in media preparation revealed that it was containing sand $93 \%$, silt $4 \%$ and clay $3 \%$. While the mechanical analysis of the new reclaimed area (from a village in rural development project in western Nubaria) indicated that it was containing sand $72 \%$, silt $8 \%$, and clay $20 \%$.

Chemical analysis of these different soil types at the beginning of the experimental sites are presented in Table (1).

\section{Mineral fertilization program:}

The fertilization of the plants was started three weeks after cultivation (on May $13^{\text {th }}$ 2010 and November $30^{\text {th }} 2010$ ). A basal dose of NPK fertilization (19:19:19) was applied as a full dose of NPK at $16 \mathrm{~g} /$ plant approximately (Doaa, 2000) used in three levels as a full dose of recommended dose
(RD) of 100, 75 and 50\% NPK). This amount of each level was divided into equal four doses as a top-dressing at biweekly intervals, the first addition was applied at 2leaves stage and the last one was added at 6leaves stage.

Plants requirement of magnesium and iron was added as $\mathrm{MgSO}_{4} .7 \mathrm{H}_{2} \mathrm{O}$ (Magnesium sulphate $=9.5 \% \mathrm{Mg}$ ) and $\mathrm{Fe}$ EDTA (Disodium Fe of chelate ethylene diamine tetraacetic acid $14 \% \mathrm{Fe}$ ), which were sprayed three times at three weeks intervals on the plant foliage until the runoff point at 150 and 75 ppm for $\mathrm{Mg}$ and Fe respectively. The first time of spraying was applied forty-five days after planting (on June $6^{\text {th }} 2010$ and December $23^{\text {th }} 2010$ ) and the last one was sprayed on July $18^{\text {th }} 2010$ and February $2^{\text {nd }} 2011$.

\section{Biofertilizer treatments:}

The biofertilizer was used either Nitrobein contained nitrogen fixing-bacteria (Azotobacter and Azospirillum) and Phosphorein (a biofertilizer contains a specific clone of bacteria which changes the unavailable triphosphate to available monophosphate) it was mixed with the surface layer of the soil $B_{0}$ (without biofertilizer), $\mathrm{B}_{1}$ (5 g Nitrobein $+5 \mathrm{~g}$ Phosphorein) and $\mathrm{B}_{2}$ (10 g Nitrobein $+10 \mathrm{~g}$ Phosphorein) per plant. It was added two times, the first one was immediately after planting and the second one was added after 45 days from the planting. (Samira and ElTayeb, 2008).

\section{Experimental layout and statistical analysis:}

The experiment layout was designed to provide a split-split plot experimental design which containing three replicates, (Snedecor and Cochran, 1974).

The whole units were represented by five different soil textures as growing media. The sub units were randomly assigned the three mineral fertilizer (NPK) levels and the sub-sub units were described the three treatments of biofertilizers. 
M.R.A. Hassan et al.

Table 1. Chemical analysis of different growing media of the experiment.

\begin{tabular}{|c|c|c|c|c|}
\hline \multirow{2}{*}{\multicolumn{2}{|c|}{ I.D. }} & \multicolumn{3}{|c|}{ Growing media } \\
\hline & & Sand & N. R. A. ${ }^{* *}$ & Peatmoss \\
\hline \multicolumn{2}{|c|}{ PH } & 7.86 & 7.89 & 4.88 \\
\hline \multicolumn{2}{|c|}{ E.C . $^{*}(\mathrm{ds} / \mathrm{m})$} & 3.66 & 13.15 & 0.54 \\
\hline Macro & $\mathrm{NO}_{3}$ & 42.0 & 252.0 & 0.00 \\
\hline Elements & $\mathbf{P}$ & 0.40 & 23.20 & 30.0 \\
\hline (Ppm) & K & 20.0 & 580.0 & 80.0 \\
\hline Cations & $\mathrm{Na}^{+}$ & 25.65 & 82.61 & 2.00 \\
\hline \multirow[t]{3}{*}{ Meq/l } & $\mathbf{K}^{+}$ & 0.10 & 7.25 & 0.18 \\
\hline & $\mathbf{C a}^{++}$ & 8.60 & 50.0 & 2.00 \\
\hline & $\mathbf{M g}^{++}$ & 2.40 & 35.0 & 0.40 \\
\hline Anions & $\mathrm{CO}_{3}^{--}$ & 0.00 & 0.00 & 0.00 \\
\hline \multirow[t]{4}{*}{ Meq/l } & $\mathrm{HCO}_{3}{ }^{-}$ & 1.80 & 4.20 & 0.60 \\
\hline & $\mathrm{Cl}^{-}$ & 7.00 & 13.0 & 4.00 \\
\hline & $\mathrm{SO}_{4}^{--}$ & 27.8 & 47.30 & 0.80 \\
\hline & & 10.94 & 12.67 & 1.83 \\
\hline
\end{tabular}

* E.C. = Electrical Conductivity.

$* *$ N. R. A. = New Reclaimed Area.

\section{Growth characteristics:}

The vegetative growth parameters were included; plant height $(\mathrm{cm})$ at flowering time, leaf area/plant $\left(\mathrm{cm}^{2}\right)$ and dry weight of leaves/spike. Spikes were cut leaving three leaves on each plant and when the plants started the showing color stage the numbers of days from planting to flowering were recorded, spike length $(\mathrm{cm})$ and time taking from planting date to showing color stage (day). Also, the data recorded for corms volume $\left(\mathrm{cm}^{3}\right)$ and number of cormels/plant.

\section{Chemical composition:}

The chemical analysis of leaves i.e. chlorophyll content (a and b) as mg/100 g leaves fresh weight were determined according to the methods described by Moran and Porath (1980).

\section{RESULTS}

\section{1- Effect of growing media, mineral and} biofertilization on vegetative growth:

\section{Plant height (cm):}

Data in Table (2) prove that the interactions between growing media and NPK levels were significant in the two seasons. It shows that the tallest plants were obtained at $100 \%$ NPK in growing media $\left(\mathrm{GM}_{3}\right)$ with values of 113.0 and $126.22 \mathrm{~cm}$ in the two seasons. While the lowest value on plant height $(73.22 \mathrm{~cm})$ was obtained on half $100 \%$ recommended doses of NPK fertilizer at $50 \%$ on the growing media $\left(\mathrm{GM}_{4}\right)$ in the first season and $(90.44 \mathrm{~cm})$ with $\mathrm{GM}_{2}$ combined with NPK at $50 \%$ in the second season.

Application of the bio-fertilizers with different growing media was recorded in Table (3). Applying the highest dose of biofertilizer $\left(B_{2}\right)$ in growing media $\left(\mathrm{GM}_{3}\right)$ gave the tallest plant height with values of 119.88 $\mathrm{cm}$ in the second season. The shortest plant $(80.33 \mathrm{~cm})$ were noticed on the untreated plants without bio-fertilizers $\left(\mathrm{B}_{0}\right)$ under growing media $\left(\mathrm{GM}_{4}\right)(80.33 \mathrm{~cm})$ in the first season.

Data in Table (3) show that plant height was increased by increasing bio-fertilizer doses. It also noted that the maximum dose of bio-fertilizer $\left(\mathrm{B}_{2}\right)$ led to increase plant height $(97.82$ and $111.59 \mathrm{~cm}$ ) more than the untreated plants with bio-fertilizers $\left(\mathrm{B}_{0}\right)$ (88.37 and $104.86 \mathrm{~cm}$ ) in the two seasons, respectively.

Data in Table (4) indicated that the tallest plants $(121.0 \mathrm{~cm})$ resulted from the $100 \%$ NPK fertilizer plus the highest dose of bio-fertilizer $\left(\mathrm{B}_{2}\right)$ in the second season. Whereas applying half recommended dose of NPK fertilizer $50 \%$ caused a decrease value 
Table 2. Average of plant height (cm) of Gladiolus grandiflorus cv. "White Prosperity" as affected by the interaction between different growing media and mineral fertilizer in seasons of 2010 and 2011.

\begin{tabular}{|c|c|c|c|c|c|c|}
\hline \multirow{3}{*}{$\begin{array}{c}\text { Growing } \\
\text { media }\end{array}$} & \multicolumn{6}{|c|}{ Mineral fertilizer \% } \\
\hline & \multicolumn{2}{|c|}{50} & \multicolumn{2}{|c|}{75} & \multicolumn{2}{|c|}{100} \\
\hline & 2010 & 2011 & 2010 & 2011 & 2010 & 2011 \\
\hline $\mathbf{G M}_{1}$ & 81.44 & 100.44 & 88.11 & 110.33 & 103.44 & 120.55 \\
\hline $\mathbf{G M}_{2}$ & 81.66 & 90.44 & 96.44 & 99.66 & 106.0 & 108.66 \\
\hline $\mathbf{G M}_{3}$ & 94.66 & 106.66 & 105.88 & 115.11 & 113.0 & 126.22 \\
\hline $\mathbf{G M}_{4}$ & 73.22 & 95.33 & 85.00 & 105.55 & 95.88 & 113.33 \\
\hline $\mathbf{G M}_{5}$ & 80.22 & 104.77 & 90.66 & 111.22 & 98.77 & 119.44 \\
\hline L.S.D.0.05 & & $2010=0.78$ & & & $2011=1.38$ & \\
\hline
\end{tabular}

L.S.D. ${ }_{0 \cdot 05}=$ least significant differences at 0.05 of probability.

Table 3. Average of plant height (cm) of Gladiolus grandiflorus cv. "White Prosperity" as affected by the interaction between growing media and bio-fertilizer in seasons of 2010 and 2011.

\begin{tabular}{|c|c|c|c|c|c|c|}
\hline \multirow{3}{*}{ Growing media } & \multicolumn{6}{|c|}{ Bio-fertilizer } \\
\hline & \multicolumn{2}{|c|}{$\mathbf{B}_{0}$} & \multicolumn{2}{|c|}{$\mathbf{B}_{1}$} & \multicolumn{2}{|c|}{$\mathbf{B}_{2}$} \\
\hline & 2010 & 2011 & 2010 & 2011 & 2010 & 2011 \\
\hline $\mathbf{G M}_{1}$ & 84.22 & 107.00 & 91.22 & 110.66 & 97.55 & 113.66 \\
\hline $\mathbf{G M}_{2}$ & 90.66 & 95.55 & 94.44 & 99.55 & 99.00 & 103.66 \\
\hline $\mathrm{GM}_{3}$ & 100.11 & 112.22 & 104.66 & 115.88 & 108.77 & 119.88 \\
\hline $\mathbf{G M}_{4}$ & 80.33 & 100.77 & 83.66 & 106.66 & 90.11 & 106.77 \\
\hline $\mathbf{G M}_{5}$ & 86.55 & 108.77 & 89.44 & 112.66 & 93.66 & 114.00 \\
\hline L.S.D. ${ }_{0.05}$ & & $2010=1.02$ & & & $2011=1.21$ & \\
\hline
\end{tabular}

L.S.D. $\cdot_{0 \cdot 05}=$ least significant differences at 0.05 of probability.

Table 4. Average of plant height (cm) of Gladiolus grandiflorus cv. "White Prosperity" as affected by the interaction between mineral fertilizer and bio-fertilizer in seasons of 2010 and 2011.

\begin{tabular}{|c|c|c|c|c|c|c|}
\hline \multirow{3}{*}{$\begin{array}{c}\text { Mineral } \\
\text { fertilizer\% }\end{array}$} & \multicolumn{6}{|c|}{ Bio-fertilizer } \\
\hline & \multicolumn{2}{|c|}{$\mathbf{B}_{0}$} & \multicolumn{2}{|c|}{$\mathbf{B}_{1}$} & \multicolumn{2}{|c|}{$\mathbf{B}_{2}$} \\
\hline & 2010 & 2011 & 2010 & 2011 & 2010 & 2011 \\
\hline 50 & 76.13 & 95.26 & 82.06 & 100.53 & 88.53 & 102.80 \\
\hline 75 & 89.66 & 105.46 & 93.20 & 108.66 & 96.80 & 111.00 \\
\hline 100 & 99.33 & 113.86 & 102.80 & 118.06 & 108.13 & 121.00 \\
\hline L.S.D. ${ }_{0.05}$ & & $2010=0.79$ & & & $2011=$ & \\
\hline
\end{tabular}

L.S.D. $0 \cdot 05=$ least significant differences at 0.05 of probability.

$(76.13 \mathrm{~cm})$ on the plant height with untreated plants with $\left(\mathrm{B}_{0}\right)$.

Data in Table (5) confirm that the interactions between growing media, NPK levels, and bio-fertilizer doses were significant in seasons of 2010 and 2011. It shows that the tallest plants (117.0 and $131.66 \mathrm{~cm}$ ) were obtained by using $100 \%$ $\mathrm{NPK}+\mathrm{B}_{2}+\mathrm{GM}_{3}$ in the two seasons.
However, the lowest in plant height $(68.0$ $\mathrm{cm}$ ) was recorded on $\mathrm{GM}_{4}+50 \% \mathrm{NPK}+\mathrm{B}_{0}$. in the first season.

Leaf area $\left(\mathrm{cm}^{2}\right)$ :

The data illustrated in Table (6) confirm that the maximum increasing of leaf area (1015.88 and $1031.55 \mathrm{~cm}^{2}$ ) was resulted in $\mathrm{GM}_{3}$ with added NPK at $100 \%$ in the two seasons, respectively. It is worth noting from 
M.R.A. Hassan et al.

Table 5. Average of plant height (cm) of Gladiolus grandiflorus cv. "White Prosperity" as affected by the interaction between different growing media, mineral fertilizer and bio-fertilizer in seasons of 2010 and 2011.

\begin{tabular}{|c|c|c|c|c|c|c|c|}
\hline \multirow{3}{*}{$\begin{array}{c}\text { Growing } \\
\text { media }\end{array}$} & \multirow{3}{*}{$\begin{array}{c}\text { Mineral } \\
\text { fertilizer } \\
\%\end{array}$} & \multicolumn{6}{|c|}{ Bio-fertilizer } \\
\hline & & \multicolumn{3}{|c|}{2010} & \multicolumn{3}{|c|}{2011} \\
\hline & & $\mathbf{B}_{0}$ & $\mathbf{B}_{1}$ & $\mathbf{B}_{2}$ & $\mathbf{B}_{0}$ & $\mathbf{B}_{1}$ & $\mathbf{B}_{2}$ \\
\hline \multirow{4}{*}{$\mathbf{G M}_{1}$} & 50 & 72.33 & 82.00 & 90.00 & 97.66 & 101.00 & 102.66 \\
\hline & 75 & 82.33 & 88.00 & 94.00 & 106.00 & 111.00 & 114.00 \\
\hline & 100 & 98.00 & 103.66 & 108.66 & 117.33 & 120.00 & 124.33 \\
\hline & 50 & 78.33 & 81.00 & 85.66 & 85.00 & 92.00 & 94.33 \\
\hline \multirow[t]{3}{*}{$\mathbf{G M}_{2}$} & 75 & 93.00 & 97.00 & 99.33 & 96.00 & 100.00 & 103.00 \\
\hline & 100 & 100.66 & 105.33 & 112.00 & 105.66 & 106.66 & 113.66 \\
\hline & 50 & 88.00 & 95.66 & 100.33 & 103.66 & 106.00 & 110.33 \\
\hline \multirow[t]{3}{*}{$\mathbf{G M}_{3}$} & 75 & 102.33 & 106.33 & 109.00 & 112.66 & 115.00 & 117.66 \\
\hline & 100 & 110.00 & 112.00 & 117.00 & 120.33 & 126.66 & 131.66 \\
\hline & 50 & 68.00 & 71.66 & 80.00 & 88.33 & 98.00 & 99.66 \\
\hline \multirow[t]{3}{*}{$\mathbf{G M}_{4}$} & 75 & 81.00 & 84.00 & 90.00 & 103.33 & 105.33 & 108.00 \\
\hline & 100 & 92.00 & 95.33 & 100.33 & 110.66 & 116.66 & 112.66 \\
\hline & 50 & 74.00 & 80.00 & 86.66 & 101.66 & 105.66 & 107.00 \\
\hline \multirow[t]{2}{*}{$\mathrm{GM}_{5}$} & 75 & 89.66 & 90.66 & 91.66 & 109.33 & 112.0 & 112.33 \\
\hline & 100 & 96.00 & 97.66 & 102.66 & 115.33 & 120.33 & 122.66 \\
\hline \multicolumn{2}{|c|}{ L.S.D. ${ }_{0.05}$} & & $2010=1.77$ & & & $2011=2.10$ & \\
\hline
\end{tabular}

L.S.D. $0 \cdot 05=$ least significant differences at 0.05 of probability.

Table 6. Average of leaf area $\left(\mathrm{cm}^{2}\right)$ of Gladiolus grandiflorus cv. "White Prosperity" as affected by the interaction between growing media and mineral fertilizer in seasons of 2010 and 2011.

\begin{tabular}{cccccccc}
\hline \multirow{2}{*}{$\begin{array}{c}\text { Growing } \\
\text { media }\end{array}$} & \multicolumn{2}{c}{ Mo } & $\mathbf{5 0}$ & \multicolumn{2}{c}{$\mathbf{7 5}$} & \multicolumn{2}{c}{$\mathbf{1 0 0}$} \\
& $\mathbf{2 0 1 0}$ & $\mathbf{2 0 1 1}$ & $\mathbf{2 0 1 0}$ & $\mathbf{2 0 1 1}$ & $\mathbf{2 0 1 0}$ & $\mathbf{2 0 1 1}$ \\
\hline $\mathbf{G M}_{\mathbf{1}}$ & 618.91 & 710.88 & 711.14 & 844.44 & 854.07 & 963.22 \\
$\mathbf{G M}_{\mathbf{2}}$ & 648.67 & 716.66 & 708.58 & 837.33 & 858.58 & 884.33 \\
$\mathbf{G M}_{\mathbf{3}}$ & 658.79 & 802.88 & 811.61 & 939.88 & 1015.88 & 1031.55 \\
$\mathbf{G M}_{\mathbf{4}}$ & 474.03 & 650.55 & 711.37 & 768.77 & 944.20 & 983.44 \\
$\mathbf{G M}_{\mathbf{5}}$ & 598.36 & 802.22 & 768.58 & 932.66 & 855.94 & 1014.66 \\
L.S.D. $\mathbf{0 . 0 5}$ & & $2010=119.13$ & & & $2011=106.66$ & \\
\hline
\end{tabular}

L.S.D. $\cdot 0 \cdot 05=$ least significant differences at 0.05 of probability.

the same Table that the leaf area varied according to different growing media and NPK fertilizers in the two seasons.

The data in Table (7) confirm that the effect of bio-fertilizers $B_{2}$ within different growing media $\left(\mathrm{GM}_{5}\right)$ gave the largest leaf area $\left(950.33 \mathrm{~cm}^{2}\right)$ in the second season.

The data in Table (8) indicated the interaction between NPK fertilizer levels and bio-fertilizers in leaf area. Fertilizing the plants with bio-fertilizers $\left(B_{2}\right)$ plus NPK at $100 \%$ resulted in a significant increase in leaf area (964.92 and $1030.46 \mathrm{~cm}^{2}$ ) in the two seasons, respectively. However, the treatment of the plants with NPK at 50\% RD (recommended dose) resulted in a significant decrease in leaf area (517.36 and 688.26 $\mathrm{cm}^{2}$ ) with the treatments of bio-fertilizers doses $\left(B_{2}\right)$ in the two seasons, respectively.

Generally, the data in Table (9) indicate the interaction between different growing media, NPK fertilizer and bio-fertilizers on leaf area. The results show that the largest increment in leaf area $\left(1040.00 \mathrm{~cm}^{2}\right)$ was obtained by using NPK at $100 \%$ RD with $\mathrm{B}_{2}$ dose in the plants which were 
Table 7. Average of leaf area $\left(\mathrm{cm}^{2}\right)$ of Gladiolus grandiflorus cv. "White Prosperity" as affected by the interaction between growing media and bio-fertilizer in seasons of 2010 and 2011.

\begin{tabular}{|c|c|c|c|c|c|c|}
\hline \multirow{3}{*}{$\begin{array}{l}\text { Growing } \\
\text { Media }\end{array}$} & \multicolumn{6}{|c|}{ Bio-fertilizer } \\
\hline & \multicolumn{2}{|c|}{$\mathbf{B}_{0}$} & \multicolumn{2}{|c|}{$\mathbf{B}_{1}$} & \multicolumn{2}{|c|}{$\mathbf{B}_{2}$} \\
\hline & 2010 & 2011 & 2010 & 2011 & 2010 & 2011 \\
\hline $\mathbf{G M}_{1}$ & 678.91 & 813.22 & 740.17 & 832.22 & 765.05 & 873.11 \\
\hline $\mathbf{G M}_{2}$ & 703.36 & 785.78 & 750.95 & 815.22 & 761.53 & 837.33 \\
\hline $\mathbf{G M}_{3}$ & 770.54 & 890.55 & 848.55 & 934.55 & 867.19 & 949.22 \\
\hline $\mathbf{G M}_{4}$ & 604.42 & 721.33 & 729.51 & 790.55 & 795.67 & 890.89 \\
\hline $\mathbf{G M}_{5}$ & 685.88 & 887.55 & 720.20 & 911.67 & 816.81 & 950.33 \\
\hline L.S.D. ${ }_{0 \cdot 05}$ & & $2010=134.94$ & & & $2011=113.63$ & \\
\hline
\end{tabular}

L.S.D. ${ }_{0 \cdot 05}=$ least significant differences at 0.05 of probability.

Table 8. Average of leaf area $\left(\mathrm{cm}^{2}\right)$ of Gladiolus grandiflorus cv. "White Prosperity" as affected by the interaction between mineral fertilizer and bio-fertilizer in seasons of 2010 and 2011.

\begin{tabular}{cccccccc}
\hline $\begin{array}{c}\text { Mineral fertilizer } \\
\text { \% }\end{array}$ & \multicolumn{3}{c}{$\mathbf{B}_{\mathbf{0}}$} & \multicolumn{3}{c}{ Bio-fertilizer } \\
& $\mathbf{2 0 1 0}$ & $\mathbf{2 0 1 1}$ & $\mathbf{2 0 1 0}$ & $\mathbf{B}_{\mathbf{1}}$ & $\mathbf{2 0 1 1}$ & $\mathbf{2 0 1 0}$ & $\mathbf{B}_{\mathbf{2}}$ \\
\hline $\mathbf{5 0}$ & 517.36 & 688.26 & 619.66 & 742.26 & 662.24 & 779.40 \\
$\mathbf{7 5}$ & 690.13 & 837.53 & 760.04 & 865.66 & 776.60 & 890.67 \\
$\mathbf{1 0 0}$ & 858.37 & 933.26 & 893.92 & 962.60 & 964.92 & 1030.46 \\
L.S.D. 0.05 & & $\mathbf{2 0 1 0}=\mathbf{1 0 4 . 5 2}$ & & & $\mathbf{2 0 1 1}=$ N.S. \\
\hline
\end{tabular}

L.S.D. $._{0 \cdot 05}=$ least significant differences at 0.05 of probability.

N.S.= non-significant differences at 0.05 of probability.

Table 9. Average of leaf area $\left(\mathrm{cm}^{2}\right)$ of Gladiolus grandiflorus cv. "White Prosperity" as affected by the interaction between growing media, mineral fertilizer and biofertilizer in seasons of 2010 and 2011.

\begin{tabular}{|c|c|c|c|c|c|c|c|}
\hline \multirow{3}{*}{$\begin{array}{l}\text { Growing } \\
\text { media }\end{array}$} & \multirow{3}{*}{$\begin{array}{c}\text { Mineral } \\
\text { fertilizer } \\
\%\end{array}$} & \multicolumn{6}{|c|}{ Bio-fertilizer } \\
\hline & & & 2010 & & & 2011 & \\
\hline & & $\mathbf{B}_{0}$ & $\mathbf{B}_{1}$ & $\mathbf{B}_{2}$ & $\mathbf{B}_{0}$ & $\mathbf{B}_{1}$ & $\mathbf{B}_{2}$ \\
\hline \multirow{3}{*}{$\mathbf{G M}_{1}$} & 50 & 605.56 & 624.53 & 626.66 & 663.00 & 712.66 & 757.00 \\
\hline & 75 & 635.60 & 732.33 & 765.50 & 827.00 & 844.33 & 862.00 \\
\hline & 100 & 795.56 & 863.66 & 903.00 & 949.66 & 939.66 & 1000.33 \\
\hline \multirow{3}{*}{$\mathbf{G M}_{2}$} & 50 & 621.46 & 662.06 & 662.50 & 661.00 & 723.00 & 766.00 \\
\hline & 75 & 677.93 & 722.8 & 725.03 & 823.33 & 832.66 & 856.00 \\
\hline & 100 & 810.70 & 868.00 & 897.06 & 873.00 & 890.00 & 890.00 \\
\hline \multirow{4}{*}{$\mathbf{G M}_{3}$} & 50 & 517.13 & 713.66 & 745.60 & 777.66 & 801.66 & 829.33 \\
\hline & 75 & 803.83 & 804.66 & 826.33 & 885.00 & 959.33 & 975.33 \\
\hline & 100 & 990.66 & 1027.33 & 1029.66 & 1009.00 & 1042.66 & 1043.00 \\
\hline & 50 & 325.00 & 528.73 & 568.36 & 576.66 & 666.00 & 709.00 \\
\hline \multirow[t]{3}{*}{$\mathbf{G M}_{4}$} & 75 & 596.66 & 758.8 & 778.66 & 721.33 & 759.00 & 826.00 \\
\hline & 100 & 891.60 & 901.00 & 1040.00 & 866.00 & 946.66 & 1137.66 \\
\hline & 50 & 517.66 & 569.33 & 708.10 & 763.00 & 808.00 & 835.66 \\
\hline \multirow[t]{2}{*}{$\mathbf{G M}_{5}$} & 75 & 736.66 & 781.63 & 787.46 & 931.00 & 933.00 & 934.00 \\
\hline & 100 & 803.33 & 809.63 & 954.86 & 968.66 & 994.00 & 1081.33 \\
\hline \multicolumn{2}{|c|}{ L.S. } & & $2010=233.72$ & & & $2011=$ N.S & \\
\hline
\end{tabular}

L.S.D. $_{0} \cdot 05=$ least significant differences at 0.05 of probability.

N.S.= non-significant differences at 0.05 of probability. 
grown in growing media $\mathrm{GM}_{4}$ in the first season. The interaction between the three factors was not significant effects in leaf area in the second season.

\section{Leaf dry weight (g):}

Data illustrated in Table (10) confirm that the heaviest leaf dry weight (7.29 and $8.34 \mathrm{~g})$ was resulted in growing media $\left(\mathrm{GM}_{5}\right.$ and $\mathrm{GM}_{3}$ ) with added NPK at $100 \%$ of RD in the two season respectively. It is worth noting from the same Table that the leaf dry weight varied according to different growing media and NPK in the two seasons.

The minimum values in the leaf dry weight was obtained at each of treatments $\left(\mathrm{GM}_{4}\right.$ and $\left.\mathrm{GM}_{2}\right)$ (2.91 $\mathrm{g}$ and $\left.4.47 \mathrm{~g}\right)$ combined with $50 \%$ NPK in the two seasons.

The data in Table (11) confirm that the effect of bio-fertilizers $\left(B_{2}\right)$ within different growing media $\left(\mathrm{GM}_{5}\right.$ and $\left.\mathrm{GM}_{3}\right)$ gave the heaviest leaf dry weight (6.28 $\mathrm{g}$ and $7.85 \mathrm{~g}$ ) in the two seasons, respectively. While, the least leaf dry weight (3.57 and 5.33g) were obtained by the treatments of $\mathrm{GM}_{3}+\mathrm{B}_{0}$ and $\mathrm{GM}_{4}+\mathrm{B}_{0}$ in the two seasons, respectively.

The data in Table (12) indicate that the interaction between NPK fertilizer levels and bio-fertilizers in leaf dry weight were recorded. Fertilizing the plants with biofertilizers $\left(B_{2}\right)$ plus NPK at $100 \%$ resulted in a significant increase in leaf dry weight (7.16 and $7.70 \mathrm{~g}$ ) in the two seasons, followed by treatment of bio-fertilizers ( $\left.\mathrm{B}_{1}\right)$ plus NPK at $100 \%$ (6.22 and $7.23 \mathrm{~g}$ ) in the two seasons, respectively. The lowest value of leaf dry weight (2.51 and $5.16 \mathrm{~g}$ ) was recorded with $50 \%$ NPK of RD without bio-fertilizers in the two seasons.

Generally, the data in Table (13) indicated the interaction between different growing media, NPK fertilizer and biofertilizers on leaf dry weight. The results show that the largest increment in leaf dry weight (8.11 and $8.76 \mathrm{~g}$ ) was obtained by using NPK at $100 \%$ of RD with $\mathrm{B}_{2}$ dose in the plants which were grown in growing media $\left(\mathrm{GM}_{5}\right)$ and $\left(\mathrm{GM}_{3}\right)$ in the two seasons, respectively.

\section{2- Effect of growing media, mineral and bio- fertilization on flowers characteristics:}

\section{Number of days from planting to showing color stage:}

The data illustrated in Table (14) confirm that using NPK at $100 \%$ combined with $\left(G_{3}\right.$ and $\left.G_{5}\right)$ led to the shortest period on the number of days to showing color (96.12 and 107.01 days) in the two seasons, respectively.

The data presented in Table (15) show that the highest doses of bio-fertilizers $\left(B_{2}\right)$ gave the shortest period on the number of days to showing color (99.82 and 104.91 days) with $\mathrm{GM}_{3}$ in the two seasons, respectively. Data in Table (16) showed that the highest dose of bio-fertilizers $\left(B_{2}\right)$ gave the shortest period on the number of days to showing color (101.51 and 111.58 days) with NPK at $100 \%$ of recommended dose.

Data in Table (17) show that the interaction between media, NPK fertilizer and bio-fertilization were non significant in seasons of 2010 and 2011. It shows that the minimum period between planting to showing color was recorded on the treatment of $\left(\mathrm{GM}_{3}+100 \% \mathrm{NPK}+\mathrm{B}_{2}\right)$ in the two seasons, respectively.

\section{Spike length (cm):}

Data presented in Table (18) revealed that the interaction between growing media and NPK fertilizers led to significant increase in the spikes length $(35.50 \mathrm{~cm})$ resulted from $100 \% \mathrm{NPK}$ and $\mathrm{GM}_{3}$ in the first season, while the shortest one (17.94 $\mathrm{cm}$ ) was obtained on $\mathrm{GM}_{4}$ combined with NPK $50 \%$ in the first season. In the second season treatment had no significant effects on spike length.

Data in Table (19) note that in the first season the interaction between growing media and bio-fertilizers led to significant increase in the spikes length $(33.57 \mathrm{~cm})$ whereas, their length reached the maximum in sandy soil + peatmoss $(1: 1)\left(\mathrm{GM}_{3}\right)$ with bio-fertilizers $\left(B_{2}\right)$ in the first season. New 
Table 10. Average of leaf dry weight (g) of Gladiolus grandiflorus cv. "White Prosperity" plants as affected by the interaction between growing media and mineral fertilizer in seasons of 2010 and 2011.

\begin{tabular}{cccccccc}
\hline \multirow{2}{*}{$\begin{array}{c}\text { Growing } \\
\text { media }\end{array}$} & \multicolumn{2}{c}{ 50 } & \multicolumn{6}{c}{ Mineral fertilizer \% } & \multicolumn{2}{c}{$\mathbf{1 0 0}$} \\
& $\mathbf{2 0 1 0}$ & $\mathbf{2 0 1 1}$ & $\mathbf{2 0 1 0}$ & $\mathbf{7 5 1 1}$ & $\mathbf{2 0 1 0}$ & $\mathbf{2 0 1 1}$ \\
\hline $\mathbf{G M}_{\mathbf{1}}$ & 3.70 & 5.61 & 4.71 & 6.56 & 6.27 & 7.34 \\
$\mathbf{G M}_{\mathbf{2}}$ & 3.19 & 4.47 & 4.77 & 5.84 & 6.39 & 6.31 \\
$\mathbf{G M}_{\mathbf{3}}$ & 3.10 & 6.71 & 4.03 & 7.43 & 5.47 & 8.34 \\
$\mathbf{G M}_{\mathbf{4}}$ & 2.91 & 4.75 & 4.32 & 5.61 & 6.11 & 6.69 \\
$\mathbf{G M}_{\mathbf{5}}$ & 3.53 & 6.44 & 5.72 & 7.02 & 7.29 & 7.78 \\
L.S.D. 0.05 & & $2010=0.14$ & & & $2011=0.11$ & \\
\hline
\end{tabular}

L.S.D. $\cdot_{0 \cdot 05}=$ least significant differences at 0.05 of probability.

Table 11. Average of leaf dry weight (g) of Gladiolus grandiflorus cv. "White Prosperity" plants as affected by the interaction between growing media and bio-fertilizer in seasons of 2010 and 2011.

\begin{tabular}{cccccccc}
\hline $\begin{array}{c}\text { Growing } \\
\text { media }\end{array}$ & \multicolumn{9}{c}{$\mathbf{B}_{\mathbf{0}}$} & \multicolumn{6}{c}{ Bio-fertilizer } & \multicolumn{2}{c}{$\mathbf{B}_{\mathbf{1}}$} & $\mathbf{B}_{\mathbf{2}}$ \\
& $\mathbf{2 0 1 0}$ & $\mathbf{2 0 1 1}$ & $\mathbf{2 0 1 0}$ & $\mathbf{2 0 1 1}$ & $\mathbf{2 0 1 0}$ & $\mathbf{2 0 1 1}$ \\
\hline $\mathbf{G M}_{\mathbf{1}}$ & 4.38 & 6.19 & 4.83 & 6.53 & 5.47 & 6.80 \\
$\mathbf{G M}_{\mathbf{2}}$ & 4.17 & 8.21 & 4.76 & 5.57 & 5.42 & 5.87 \\
$\mathbf{G M}_{\mathbf{3}}$ & 3.57 & 7.15 & 4.26 & 7.48 & 4.76 & 7.85 \\
$\mathbf{G M}_{\mathbf{4}}$ & 3.87 & 5.33 & 4.52 & 5.64 & 4.96 & 6.08 \\
$\mathbf{G M}_{\mathbf{5}}$ & 9.66 & 6.81 & 5.80 & 7.05 & 6.28 & 7.38 \\
L.S.D. $\mathbf{0}_{\mathbf{0} 05}$ & & $2010=0.13$ & & & $2011=0.07$ & \\
\hline
\end{tabular}

L.S.D. $\cdot 0 \cdot 05=$ least significant differences at 0.05 of probability.

Table 12. Average of leaf dry weight (g) of Gladiolus grandiflorus cv. "White Prosperity" plants as affected by the interaction between mineral fertilizer and bio-fertilizer in seasons of 2010 and 2011.

\begin{tabular}{cccccccc}
\hline $\begin{array}{c}\text { Mineral fertilizer } \\
\mathbf{\%}\end{array}$ & \multicolumn{2}{c}{$\mathbf{B}_{\mathbf{0}}$} & \multicolumn{9}{c}{ Bio-fertilizer } \\
& $\mathbf{2 0 1 0}$ & $\mathbf{2 0 1 1}$ & $\mathbf{2 0 1 0}$ & $\mathbf{2 0 1 1}$ & $\mathbf{2 0 1 0}$ & $\mathbf{2 0 1 1}$ \\
\hline $\mathbf{5 0}$ & 2.51 & 5.16 & 3.97 & 5.63 & 3.88 & 5.99 \\
$\mathbf{7 5}$ & 4.34 & 6.29 & 4.69 & 6.49 & 5.10 & 6.69 \\
$\mathbf{1 0 0}$ & 5.55 & 6.96 & 6.22 & 7.23 & 7.16 & 7.70 \\
L.S.D. 0.05 & & $2010=0.10$ & & & $2011=0.06$ & \\
\hline
\end{tabular}

L.S.D. $\cdot_{0 \cdot 05}=$ least significant differences at 0.05 of probability. 
Table 13. Average of leaf dry weight (g) of Gladiolus grandiflorus cv. "White Prosperity" plants as affected by the interaction between growing media, mineral fertilizer and bio-fertilizer in seasons of 2010 and 2011.

\begin{tabular}{|c|c|c|c|c|c|c|c|}
\hline \multirow{3}{*}{$\begin{array}{l}\text { Growing } \\
\text { media }\end{array}$} & \multirow{3}{*}{$\begin{array}{c}\text { Mineral } \\
\text { fertilizer } \\
\%\end{array}$} & \multicolumn{6}{|c|}{ Bio-fertilizer } \\
\hline & & & 2010 & & & 2011 & \\
\hline & & $\mathbf{B}_{0}$ & $\mathbf{B}_{1}$ & $\mathbf{B}_{2}$ & $\mathbf{B}_{0}$ & $\mathbf{B}_{1}$ & $\mathbf{B}_{2}$ \\
\hline \multirow{3}{*}{$\mathbf{G M}_{1}$} & 50 & 3.36 & 3.73 & 4.02 & 5.23 & 5.63 & 5.98 \\
\hline & 75 & 4.31 & 4.74 & 5.10 & 6.30 & 6.64 & 6.74 \\
\hline & 100 & 5.48 & 6.02 & 7.30 & 7.02 & 7.31 & 7.69 \\
\hline & 50 & 2.59 & 3.15 & 3.83 & 3.83 & 4.51 & 5.06 \\
\hline \multirow{3}{*}{$\mathbf{G M}_{2}$} & 75 & 4.42 & 4.70 & 5.20 & 5.70 & 5.85 & 5.99 \\
\hline & 100 & 5.52 & 6.45 & 7.22 & 6.11 & 6.35 & 6.57 \\
\hline & 50 & 2.46 & 3.29 & 3.53 & 6.30 & 6.77 & 7.06 \\
\hline \multirow{3}{*}{$\mathbf{G M}_{3}$} & 75 & 3.77 & 4.02 & 4.30 & 7.20 & 7.37 & 7.72 \\
\hline & 100 & 4.48 & 5.47 & 6.46 & 7.95 & 8.31 & 8.76 \\
\hline & 50 & 2.09 & 3.22 & 3.42 & 4.37 & 4.75 & 5.14 \\
\hline \multirow[t]{3}{*}{$\mathbf{G M}_{4}$} & 75 & 3.99 & 4.22 & 4.76 & 5.40 & 5.60 & 5.83 \\
\hline & 100 & 5.53 & 6.11 & 6.70 & 6.24 & 6.55 & 7.28 \\
\hline & 50 & 2.03 & 3.97 & 4.59 & 6.07 & 6.50 & 6.74 \\
\hline \multirow[t]{2}{*}{$\mathbf{G M}_{5}$} & 75 & 5.23 & 5.78 & 6.15 & 6.85 & 7.02 & 7.19 \\
\hline & 100 & 6.73 & 7.04 & 8.11 & 7.50 & 7.64 & 8.21 \\
\hline \multicolumn{2}{|c|}{ L.S.D. 0.05} & & $2010=0.23$ & & & $2011=0.13$ & \\
\hline
\end{tabular}

L.S.D. $0 \cdot 05=$ least significant differences at 0.05 of probability.

Table 14. Average of number of days to showing color of Gladiolus grandiflorus cv. "White Prosperity" plants as affected by the interaction between growing media and mineral fertilizer in seasons of 2010 and 2011.

\begin{tabular}{|c|c|c|c|c|c|c|}
\hline \multirow{3}{*}{$\begin{array}{l}\text { Growing } \\
\text { media }\end{array}$} & \multicolumn{6}{|c|}{ Mineral fertilizer \% } \\
\hline & \multicolumn{2}{|c|}{50} & \multicolumn{2}{|c|}{75} & \multicolumn{2}{|c|}{100} \\
\hline & 2010 & 2011 & 2010 & 2011 & 2010 & 2011 \\
\hline $\mathbf{G M}_{1}$ & 115.75 & 123.65 & 112.25 & 122.48 & 110.80 & 120.15 \\
\hline $\mathbf{G M}_{2}$ & 111.76 & 117.48 & 110.05 & 114.72 & 109.90 & 114.27 \\
\hline $\mathbf{G M}_{3}$ & 106.00 & 108.07 & 102.74 & 108.03 & 96.12 & 107.44 \\
\hline $\mathbf{G M}_{4}$ & 111.27 & 124.00 & 105.96 & 120.66 & 105.45 & 118.33 \\
\hline $\mathbf{G M}_{5}$ & 107.60 & 114.44 & 104.24 & 111.00 & 98.32 & 107.01 \\
\hline L.S.D. 0.05 & & $2010=0.91$ & & & $2011=0.73$ & \\
\hline
\end{tabular}

L.S.D. $0 \cdot 05=$ least significant differences at 0.05 of probability.

Table 15. Average of number of days to showing color of Gladiolus grandiflorus cv. "White Prosperity" plants as affected by the interaction between growing media and bio-fertilizer in seasons of 2010 and 2011.

\begin{tabular}{|c|c|c|c|c|c|c|}
\hline \multirow{3}{*}{$\begin{array}{c}\text { Growing } \\
\text { media }\end{array}$} & \multicolumn{6}{|c|}{ Bio-fertilizer } \\
\hline & \multicolumn{2}{|c|}{$\mathbf{B}_{\mathbf{0}}$} & \multicolumn{2}{|c|}{$\mathbf{B}_{1}$} & \multicolumn{2}{|c|}{$\mathbf{B}_{2}$} \\
\hline & 2010 & 2011 & 2010 & 2011 & 2010 & 2011 \\
\hline $\mathbf{G M}_{1}$ & 114.23 & 122.98 & 113.38 & 121.87 & 111.20 & 121.43 \\
\hline $\mathbf{G M}_{2}$ & 112.28 & 116.67 & 110.73 & 115.76 & 108.71 & 114.04 \\
\hline $\mathbf{G M}_{3}$ & 102.70 & 110.75 & 102.34 & 107.88 & 99.82 & 104.91 \\
\hline $\mathbf{G M}_{4}$ & 109.84 & 122.66 & 107.64 & 120.44 & 105.21 & 119.88 \\
\hline $\begin{array}{c}\text { GM }_{5} \\
\text { L.S.D. }{ }_{0.05}\end{array}$ & 105.53 & $\begin{array}{c}112.22 \\
2010=0.83\end{array}$ & 103. 23 & 110.77 & $\begin{array}{c}101.40 \\
2011=0.63\end{array}$ & 109.45 \\
\hline
\end{tabular}

L.S.D. ${ }_{0} \cdot 05=$ least significant differences at 0.05 of probability. 
Table 16. Average of number of days to showing color of Gladiolus grandiflorus cv. "White Prosperity" plants as affected by the interaction between mineral fertilizer and bio-fertilizer in seasons of 2010 and 2011.

\begin{tabular}{cccccccc}
\hline $\begin{array}{c}\text { Mineral } \\
\text { fertilizer } \\
\mathbf{\%}\end{array}$ & \multicolumn{2}{c}{$\mathbf{B}_{\mathbf{0}}$} & \multicolumn{3}{c}{ Bio-fertilizer } \\
$\mathbf{B}_{\mathbf{1}}$ & $\mathbf{2 0 1 0}$ & $\mathbf{2 0 1 1}$ & $\mathbf{2 0 1 0}$ & $\mathbf{2 0 1 1}$ & $\mathbf{2 0 1 0}$ & $\mathbf{B}_{\mathbf{2}}$ \\
\hline $\mathbf{5 0}$ & 112.06 & 119.09 & 110.7 & 117.16 & 108.68 & 116.34 \\
$\mathbf{7 5}$ & 108.55 & 116.88 & 106.99 & 115.34 & 105.61 & 113.91 \\
$\mathbf{1 0 0}$ & 106.14 & 115.20 & 104.7 & 113.54 & 101.51 & 111.58 \\
L.S.D. $\mathbf{0 . 0 5}$ & & $2010=0.64$ & & & $2011=0.49$ & \\
\hline
\end{tabular}

L.S.D. $\cdot 0 \cdot 05=$ least significant differences at 0.05 of probability.

Table 17. Average of number of days to showing color of Gladiolus grandiflorus cv. "White Prosperity" plants as affected by the interaction between growing media, mineral fertilizer and bio-fertilizer doses in seasons of 2010 and 2011.

\begin{tabular}{|c|c|c|c|c|c|c|c|}
\hline \multirow{3}{*}{$\begin{array}{l}\text { Growing } \\
\text { media }\end{array}$} & \multirow{3}{*}{$\begin{array}{c}\text { Mineral } \\
\text { fertilizer } \\
\%\end{array}$} & \multicolumn{6}{|c|}{ Bio-fertilizer } \\
\hline & & \multicolumn{3}{|c|}{2010} & \multicolumn{3}{|c|}{2011} \\
\hline & & $\mathbf{B}_{\mathbf{0}}$ & $\mathbf{B}_{1}$ & $\mathbf{B}_{2}$ & $\mathbf{B}_{\mathbf{0}}$ & $\mathbf{B}_{1}$ & $\mathbf{B}_{2}$ \\
\hline & 50 & 116.90 & 116.06 & 114.30 & 124.33 & 123.13 & 123.50 \\
\hline \multirow[t]{3}{*}{$\mathbf{G M}_{1}$} & 75 & 113.03 & 112.60 & 111.13 & 123.53 & 122.50 & 121.43 \\
\hline & 100 & 112.76 & 111.47 & 108.16 & 121.10 & 120.0 & 119.36 \\
\hline & 50 & 113.30 & 112.00 & 110.00 & 118.90 & 117.33 & 116.23 \\
\hline \multirow[t]{3}{*}{$\mathbf{G M}_{2}$} & 75 & 111.56 & 109.83 & 108.76 & 115.53 & 114.90 & 113.73 \\
\hline & 100 & 112.00 & 110.36 & 107.36 & 115.60 & 115.06 & 112.16 \\
\hline & 50 & 106.43 & 107.33 & 104.23 & 110.90 & 107.33 & 106.00 \\
\hline \multirow[t]{3}{*}{$\mathbf{G M}_{3}$} & 75 & 104.23 & 102.96 & 101.03 & 110.70 & 108.66 & 104.73 \\
\hline & 100 & 97.43 & 96.73 & 94.20 & 110.66 & 107.66 & 104.00 \\
\hline & 50 & 113.90 & 110.83 & 109.10 & 125.66 & 123.66 & 122.66 \\
\hline \multirow[t]{3}{*}{$\mathbf{G M}_{4}$} & 75 & 107.76 & 105.90 & 104.23 & 122.33 & 119.66 & 120.00 \\
\hline & 100 & 107.86 & 106.20 & 102.30 & 120.0 & 118.00 & 117.00 \\
\hline & 50 & 109.76 & 107.26 & 105.76 & 115.66 & 114.33 & 113.33 \\
\hline \multirow[t]{2}{*}{$\mathbf{G M}_{5}$} & 75 & 106.16 & 103.66 & 102.90 & 112.33 & 111.00 & 109.66 \\
\hline & 100 & 100.66 & 98.76 & 95.53 & 108.66 & 107.00 & 105.36 \\
\hline \multicolumn{2}{|c|}{ L.S.D. ${ }_{0.05}$} & & $2010=$ N.S. & & & $2011=$ N.S & \\
\hline
\end{tabular}

L.S.D. $._{0.05}=$ least significant differences at 0.05 of probability.

N.S.= non-significant differences at 0.05 of probability.

Table 18. Average of spike length (cm) of Gladiolus grandiflorus cv. "White Prosperity" plants as affected by the interaction between growing media and mineral fertilizer in seasons of 2010 and 2011.

\begin{tabular}{|c|c|c|c|c|c|c|}
\hline \multirow{3}{*}{ Growing media } & \multicolumn{6}{|c|}{ Mineral fertilizer \% } \\
\hline & \multicolumn{2}{|c|}{50} & \multicolumn{2}{|c|}{75} & \multicolumn{2}{|c|}{100} \\
\hline & 2010 & 2011 & 2010 & 2011 & 2010 & 2011 \\
\hline $\mathbf{G M}_{1}$ & 23.66 & 24.65 & 28.44 & 29.88 & 33.22 & 34.33 \\
\hline $\mathbf{G M}_{2}$ & 23.33 & 35.66 & 25.88 & 31.44 & 28.33 & 37.00 \\
\hline $\mathbf{G M}_{3}$ & 28.68 & 36.86 & 31.76 & 40.15 & 35.50 & 39.76 \\
\hline $\mathbf{G M}_{4}$ & 17.94 & 25.32 & 25.05 & 29.85 & 30.38 & 35.33 \\
\hline $\mathbf{G M}_{5}$ & 24.11 & 29.23 & 29.11 & 34.04 & 33.88 & 38.68 \\
\hline L.S.D. $0 \cdot 05$ & & $2010=0.71$ & & & $2011=$ N.S. & \\
\hline
\end{tabular}

L.S.D.0.05 = least significant differences at 0.05 of probability.

N.S.= non-significant differences at 0.05 of probability. 
Table 19. Average of spike length (cm) of Gladiolus grandiflorus cv. "White Prosperity" plants as affected by the interaction between growing media and bio-fertilizers doses in seasons of 2010 and 2011.

\begin{tabular}{|c|c|c|c|c|c|c|}
\hline \multirow{3}{*}{$\begin{array}{l}\text { Growing } \\
\text { media }\end{array}$} & \multicolumn{6}{|c|}{ Bio-fertilizer } \\
\hline & \multicolumn{2}{|c|}{$\mathbf{B}_{0}$} & \multicolumn{2}{|c|}{$\mathbf{B}_{1}$} & \multicolumn{2}{|c|}{$\mathbf{B}_{2}$} \\
\hline & 2010 & 2011 & 2010 & 2011 & 2010 & 2011 \\
\hline $\mathbf{G M}_{1}$ & 26.88 & 27.82 & 28.33 & 29.53 & 30.11 & 31.52 \\
\hline $\mathbf{G M}_{2}$ & 24.88 & 29.22 & 25.77 & 31.55 & 26.88 & 33.33 \\
\hline $\mathbf{G M}_{3}$ & 30.47 & 35.20 & 31.90 & 40.40 & 33.57 & 41.18 \\
\hline $\mathbf{G M}_{4}$ & 22.44 & 28.33 & 24.38 & 30.08 & 26.55 & 32.08 \\
\hline $\mathbf{G M}_{5}$ & 27.66 & 32.12 & 28.88 & 33.98 & 30.55 & 35.86 \\
\hline L.S.D. ${ }_{0 \cdot 05}$ & & $2010=0.58$ & & & $2011=$ N.S. & \\
\hline
\end{tabular}

L.S.D. ${ }_{0 \cdot 05}=$ least significant differences at 0.05 of probability.

N.S.= non-significant differences at 0.05 of probability.

reclaimed soil $\left(\mathrm{GM}_{4}\right)$ without biofertilizers $\left(B_{0}\right)$ gave the lowest value of spikes length $(22.44 \mathrm{~cm})$ in the first season, while there was non significant between them in the second season.

The interaction between NPK fertilization and bio-fertilization was non significant in the two growing seasons, as show in Table (20).

Data given in Table (21) showed that the interaction between growing media, NPK fertilizers and bio-fertilizers led to an increase in the spikes length (37.66 and $44.50 \mathrm{~cm})$ on sandy soil $50 \%+$ peatmoss $50 \%\left(\mathrm{GM}_{3}\right)$ plus $100 \% \mathrm{NPK}+\mathrm{B}_{2}$ in the two seasons, respectively. Followed by the treatment $\mathrm{GM}_{3}+100 \% \mathrm{NPK}+\mathrm{B}_{1}$ (35.23 and $43.43 \mathrm{~cm}$ ) in the two seasons. $\mathrm{GM}_{4}$ fertilized with 50\% NPK without biofertilizer and also $\left(\mathrm{GM}_{1}+50 \% \mathrm{NPK}+\mathrm{B}_{0}\right)$ gave the lowest value of spikes length $(16.0$ and $21.66 \mathrm{~cm})$ in the first season, respectively.

3- Effect of growing media, mineral and bio-fertilization on corms and cormels production:

\section{Corm volume $\left(\mathrm{cm}^{3}\right)$ :}

Data presented in Table (22) reveal that the interaction between growing media and NPK fertilizers levels led to significant increase in the corm volume $\left(\mathrm{cm}^{3}\right)$ in the two seasons. Fertilizing the plants with NPK at $100 \% \mathrm{RD}$ gave the maximum corm volume (12.0 and $19.11 \mathrm{~cm}^{3}$ ) on $\mathrm{GM}_{3}$ in the first season and in the second season, respectively. The treatments of NPK fertilizers at $50 \%$ on $\mathrm{GM}_{2}$ resulted in a decrease in corm volume $\left(3.33 \mathrm{~cm}^{3}\right)$ in the first season.

Data in Table (23) presented that the interaction between growing media and biofertilizer doses led to significant increase in the corm volume $\left(\mathrm{cm}^{3}\right)$ in the two seasons. The maximum corm volume was given by the combination treatment of $\mathrm{GM}_{3}$ plus $\mathrm{B}_{2}$ (11.66 and $16.66 \mathrm{~cm}^{3}$ ) in the two seasons, respectively.

Data in Table (24) show that the interaction between mineral (NPK) and biofertilizer (B) led to significant increase in the corm volume in the two seasons, respectively. Fertilizing the plants with NPK at $100 \% \mathrm{RD}$ with $\mathrm{B}_{2}$ give the maximum corm volume $\left(7.13\right.$ and $\left.17.33 \mathrm{~cm}^{3}\right)$ in the two seasons, respectively.

The data in Table (25) clear that there were significant differences in corm volume between the growing media, NPK fertilizer and bio-fertilizers in the second season. The maximum values on corm volume were recorded on the treatment: $\mathrm{GM}_{3}+100 \%$ $\mathrm{NPK}+\mathrm{B}_{2},\left(20.66 \mathrm{~cm}^{3}\right)$ in the second season. The lowest value was resulted in the treatment of $\mathrm{GM}_{4}+50 \% \mathrm{NPK}+\mathrm{B}_{0}(8.33$ $\mathrm{cm}^{3}$ ) in the second season. This interaction was non significant in the first season. 
Table 20. Average of spike length (cm) of Gladiolus grandiflorus cv. "White Prosperity" plants as affected by the interaction between mineral fertilizer and biofertilizers in seasons of 2010 and 2011.

\begin{tabular}{cccccccc}
\hline $\begin{array}{c}\text { Mineral fertilizer } \\
\%\end{array}$ & \multicolumn{3}{c}{$\mathbf{B}_{\mathbf{0}}$} & \multicolumn{3}{c}{ Bio-fertilizer } \\
& $\mathbf{2 0 1 0}$ & $\mathbf{2 0 1 1}$ & $\mathbf{2 0 1 0}$ & $\mathbf{2 0 1 1}$ & $\mathbf{2 0 1 0}$ & $\mathbf{B}_{\mathbf{1}}$ \\
\hline $\mathbf{5 0}$ & 21.93 & 26.10 & 23.36 & 28.53 & 25.34 & 30.41 \\
$\mathbf{7 5}$ & 26.80 & 31.59 & 28.02 & 33.11 & 29.33 & 34.52 \\
$\mathbf{1 0 0}$ & 30.68 & 33.92 & 32.18 & 37.68 & 33.93 & 39.46 \\
L.S.D. $\mathbf{0}_{\mathbf{0 5}}$ & & 2010=N.S. & & & 2011=N.S. & \\
\hline
\end{tabular}

L.S.D. $0 \cdot 05=$ least significant differences at 0.05 of probability.

N.S.= non-significant differences at 0.05 of probability.

Table 21. Average of spike length (cm) of Gladiolus grandiflours cv. "White Prosperity" plants as affected by the interaction between growing media, mineral fertilizer and bio-fertilizer in seasons of 2010 and 2011.

\begin{tabular}{|c|c|c|c|c|c|c|c|}
\hline \multirow{3}{*}{$\begin{array}{l}\text { Growing } \\
\text { media }\end{array}$} & \multirow{3}{*}{$\begin{array}{c}\text { Mineral } \\
\text { fertilizer } \\
\% \\
\end{array}$} & \multicolumn{6}{|c|}{ Bio-fertilizer } \\
\hline & & \multicolumn{3}{|c|}{2010} & \multicolumn{3}{|c|}{2011} \\
\hline & & $\mathbf{B}_{\mathbf{0}}$ & $\mathbf{B}_{1}$ & $\mathbf{B}_{2}$ & $\mathbf{B}_{\mathbf{0}}$ & $\mathbf{B}_{1}$ & $\mathbf{B}_{2}$ \\
\hline & 50 & 21.66 & 24.00 & 25.33 & 21.80 & 24.43 & 27.73 \\
\hline \multirow[t]{3}{*}{$\mathbf{G M}_{1}$} & 75 & 27.33 & 28.00 & 30.00 & 28.66 & 29.83 & 31.16 \\
\hline & 100 & 31.66 & 33.50 & 35.00 & 33.00 & 34.33 & 35.66 \\
\hline & 50 & 22.33 & 23.00 & 24.66 & 23.00 & 26.33 & 27.66 \\
\hline \multirow[t]{3}{*}{$\mathbf{G M}_{2}$} & 75 & 25.00 & 26.00 & 26.66 & 29.33 & 31.33 & 33.66 \\
\hline & 100 & 27.33 & 28.33 & 29.33 & 35.33 & 37.00 & 38.66 \\
\hline & 50 & 27.00 & 28.66 & 30.40 & 34.93 & 37.43 & 38.23 \\
\hline \multirow[t]{3}{*}{$\mathbf{G M}_{3}$} & 75 & 30.38 & 31.80 & 32.66 & 39.30 & 40.33 & 40.83 \\
\hline & 100 & 33.60 & 35.23 & 37.66 & 31.37 & 43.43 & 44.50 \\
\hline & 50 & 16.00 & 17.83 & 20.00 & 23.76 & 25.10 & 27.10 \\
\hline \multirow[t]{3}{*}{$\mathbf{G M}_{4}$} & 75 & 22.50 & 25.33 & 27.33 & 28.35 & 30.15 & 31.06 \\
\hline & 100 & 28.83 & 30.00 & 32.33 & 32.90 & 35.00 & 38.10 \\
\hline & 50 & 22.66 & 23.33 & 26.33 & 27.00 & 29.37 & 31.33 \\
\hline \multirow[t]{2}{*}{$\mathbf{G M}_{5}$} & 75 & 28.33 & 29.00 & 30.00 & 32.33 & 33.93 & 35.86 \\
\hline & 100 & 32.00 & 34.33 & 35.33 & 37.03 & 38.63 & 40.40 \\
\hline \multicolumn{2}{|c|}{ L.S.D. ${ }_{0.05}$} & & $2010=1.02$ & & & $2011=1.21$ & \\
\hline
\end{tabular}

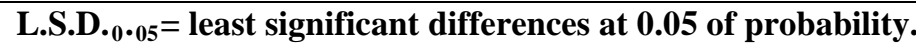

Table 22. Average of corm volume $\left(\mathrm{cm}^{3}\right)$ of Gladiolus grandiflorus cv. "White Prosperity" plants as affected by the interaction between different growing media and mineral fertilizer in season of 2010 and 2011.

\begin{tabular}{cccccccc}
\hline \multirow{2}{*}{$\begin{array}{c}\text { Growing } \\
\text { media }\end{array}$} & \multicolumn{2}{c}{$\mathbf{5 0}$} & \multicolumn{2}{c}{ Mineral fertilizer \% } \\
& $\mathbf{2 0 1 0}$ & $\mathbf{2 0 1 1}$ & $\mathbf{2 0 1 0}$ & $\mathbf{2 0 1 1}$ & $\mathbf{2 0 1 0}$ & $\mathbf{1 0 0}$ \\
\hline $\mathbf{G M}_{\mathbf{1}}$ & 5.11 & 9.55 & 4.55 & 10.55 & 5.44 & 12.00 \\
$\mathbf{G M}_{\mathbf{2}}$ & 3.33 & 10.22 & 3.55 & 13.22 & 3.88 & 16.33 \\
$\mathbf{G M}_{\mathbf{3}}$ & 10.55 & 11.55 & 10.22 & 14.77 & 12.00 & 19.11 \\
$\mathbf{G M}_{\mathbf{4}}$ & 3.77 & 8.77 & 3.88 & 11.00 & 3.66 & 14.77 \\
$\mathbf{G M}_{\mathbf{5}}$ & 5.11 & 10.33 & 5.77 & 14.11 & 7.55 & 17.88 \\
L.S.D.0.05 & & $2010=1.18$ & & & $2011=0.43$ & \\
\hline
\end{tabular}

L.S.D. ${ }_{0.05}=$ least significant differences at 0.05 of probability. 
Table 23. Average of corm volume $\left(\mathrm{cm}^{3}\right)$ of Gladiolus grandiflorus cv. "White Prosperity" plants as affected by the interaction between different growing media and bio-fertilizer in seasons of 2010 and 2011.

\begin{tabular}{|c|c|c|c|c|c|c|}
\hline \multirow{3}{*}{$\begin{array}{l}\text { Growing } \\
\text { media }\end{array}$} & \multicolumn{6}{|c|}{ Bio-fertilizer } \\
\hline & \multicolumn{2}{|c|}{$\mathbf{B}_{0}$} & \multicolumn{2}{|c|}{$\mathrm{B}_{1}$} & \multicolumn{2}{|c|}{$\mathbf{B}_{2}$} \\
\hline & 2010 & 2011 & 2010 & 2011 & 2010 & 2011 \\
\hline $\mathbf{G M}_{1}$ & 5.11 & 9.00 & 4.44 & 10.66 & 5.55 & 12.44 \\
\hline $\mathbf{G M}_{2}$ & 3.55 & 12.22 & 3.22 & 13.22 & 4.00 & 14.33 \\
\hline $\mathbf{G M}_{3}$ & 10.22 & 13.77 & 10.88 & 15.00 & 11.66 & 16.66 \\
\hline $\mathbf{G M}_{4}$ & 3.88 & 10.55 & 3.22 & 11.55 & 4.44 & 12.44 \\
\hline $\mathbf{G M}_{5}$ & 5.77 & 12.77 & 6.00 & 14.33 & 6.66 & 15.22 \\
\hline L.S.D. $\mathbf{0 . 0 5}$ & & $2010=0.67$ & & & $2011=0.37$ & \\
\hline
\end{tabular}

L.S.D. $\cdot 0 \cdot 05=$ least significant differences at 0.05 of probability.

Table 24. Average of corm volume $\left(\mathrm{cm}^{3}\right)$ of Gladiolus grandiflorus cv. "White Prosperity" plants as affected by the interaction between mineral fertilizer and bio-fertilizer in seasons of 2010 and 2011.

\begin{tabular}{|c|c|c|c|c|c|c|}
\hline \multirow{3}{*}{$\begin{array}{c}\text { Mineral } \\
\text { fertilizer } \\
\%\end{array}$} & \multicolumn{6}{|c|}{ Bio-fertilizer } \\
\hline & \multicolumn{2}{|c|}{$\mathbf{B}_{0}$} & \multicolumn{2}{|c|}{$\mathbf{B}_{1}$} & \multicolumn{2}{|c|}{$\mathbf{B}_{2}$} \\
\hline & 2010 & 2011 & 2010 & 2011 & 2010 & 2011 \\
\hline 50 & 5.60 & 9.06 & 4.86 & 10.00 & 6.26 & 11.20 \\
\hline 75 & 5.40 & 11.33 & 5.53 & 12.73 & 5.86 & 14.13 \\
\hline 100 & 6.13 & 14.60 & 6.26 & 16.13 & 7.13 & 17.33 \\
\hline L.S.D. $\mathbf{0 . 0 5}$ & & $2010=0.30$ & & & $2011=0.2$ & \\
\hline
\end{tabular}

L.S.D. $0 \cdot 05=$ least significant differences at 0.05 of probability.

Table 25. Average of corm volume $\left(\mathrm{cm}^{3}\right)$ of Gladiolus grandiflorus cv. "White Prosperity" plants as affected by the interaction between different growing media, mineral fertilizers and bio-fertilizer in seasons of 2010 and 2011.

\begin{tabular}{|c|c|c|c|c|c|c|c|}
\hline \multirow{3}{*}{$\begin{array}{l}\text { Growing } \\
\text { Media }\end{array}$} & \multirow{3}{*}{$\begin{array}{c}\text { Mineral } \\
\text { fertilizer } \\
\%\end{array}$} & \multicolumn{6}{|c|}{ Bio-fertilizer } \\
\hline & & & 2010 & & & 2011 & \\
\hline & & $\mathbf{B}_{0}$ & $\mathbf{B}_{1}$ & $\mathbf{B}_{2}$ & $\mathbf{B}_{0}$ & $\mathbf{B}_{1}$ & $\mathbf{B}_{2}$ \\
\hline \multirow{4}{*}{$\mathbf{G M}_{1}$} & 50 & 5.00 & 4.00 & 6.33 & 8.33 & 9.00 & 11.33 \\
\hline & 75 & 4.66 & 4.33 & 4.66 & 8.66 & 10.66 & 12.33 \\
\hline & 100 & 5.66 & 5.00 & 5.66 & 10.00 & 12.33 & 13.66 \\
\hline & 50 & 3.00 & 2.66 & 4.33 & 9.33 & 10.00 & 11.33 \\
\hline \multirow[t]{3}{*}{$\mathbf{G M}_{2}$} & 75 & 3.66 & 3.33 & 3.66 & 12.00 & 13.33 & 14.33 \\
\hline & 100 & 4.00 & 3.66 & 4.00 & 15.33 & 16.33 & 17.33 \\
\hline & 50 & 11.00 & 10.00 & 10.66 & 10.33 & 11.66 & 12.66 \\
\hline \multirow[t]{3}{*}{$\mathbf{G M}_{3}$} & 75 & 9.00 & 10.66 & 11.00 & 13.33 & 14.33 & 16.66 \\
\hline & 100 & 10.66 & 12.00 & 13.33 & 17.66 & 19.00 & 20.66 \\
\hline & 50 & 4.00 & 3.00 & 4.33 & 8.33 & 9.00 & 9.00 \\
\hline \multirow[t]{3}{*}{$\mathbf{G M}_{4}$} & 75 & 4.33 & 3.33 & 4.03 & 10.00 & 11.00 & 12.00 \\
\hline & 100 & 3.33 & 3.33 & 4.33 & 13.33 & 14.66 & 16.33 \\
\hline & 50 & 5.00 & 4.66 & 5.66 & 9.00 & 10.33 & 11.66 \\
\hline \multirow[t]{2}{*}{$\mathbf{G M}_{5}$} & 75 & 5.33 & 6.00 & 6.00 & 12.66 & 14.33 & 15.33 \\
\hline & 100 & 7.00 & 7.33 & 8.33 & 16.33 & 18.33 & 18.66 \\
\hline \multicolumn{2}{|c|}{ L.S.D. 0.05} & & $2010=0.79$ & & & $2011=0.65$ & \\
\hline
\end{tabular}

L.S.D. $\cdot_{05}=$ least significant differences at 0.05 of probability. 


\section{Number of cormlets per plant:}

From data in Table (26) it can be observed that the interaction between media and NPK fertilizer was significant on the number of cormlets/plant (102.66) with $\mathrm{GM}_{5}$ $+100 \%$ NPK in the first season, and (124.44) at $\mathrm{GM}_{3}+100 \%$ NPK in the second season. The lowest number of cormlets/plant (65.77 and 69.11) was recorded in $\mathrm{GM}_{1}+$ $50 \%$ NPK in the two seasons, respectively.

The data illustrated in Table (27) confirm that using bio-fertilizers doses led to significant increase in number of cormlets/plant regardless the different growing media. The highest doses $\left(\mathrm{B}_{2}\right)$ of biofertilizer led to increase the number of cormlets/plant (101.55) combined with GM3 in the first season. The treatment of $\mathrm{GM}_{3}+$ $\mathrm{B}_{1}$ give the maximum number of cormlets/plant (123.55), followed by treatment of $\mathrm{GM}_{3}+\mathrm{B}_{2}$ (119.0). Whereas, plants which were received $\mathrm{B}_{0}$ (without biofertilizers doses) with $\mathrm{GM}_{4}$ and $\mathrm{GM}_{1}$ decreased the number of cormlets/plant (64.66 and 73.44) in the two seasons, respectively.

Data presented in Table (28) show that the interaction between NPK fertilizer and bio-fertilization were significant in the two seasons. The longest number of cormlets/plant (97.13 and 104.60) were resulted when adding NPK at $100 \%$ combined with $\mathrm{B}_{2}$ in the two seasons. While the lowest value on number of cormlets/plant (69.06 and 80.40) were obtained with 50\% $\mathrm{NPK}+\mathrm{B}_{0}$ in the two seasons.

Data illustrated in Table (29) confirm that the interaction between growing media, NPK fertilizer levels and bio-fertilizer doses were significant in the two seasons. Using NPK at $100 \%$ combined with $\mathrm{B}_{2}$ on $\mathrm{GM}_{3}$ and $\mathrm{GM}_{5}$ led to an increase number of cormlets/plant (110.0 and 113.33) in the first season.

In the second season, applying NPK at $50 \%+\mathrm{GM}_{3}+\mathrm{B}_{1}$ caused an increase in number of cormlets/plant (130.33), followed by the following treatments: $\mathrm{GM}_{3}+75 \%$
$\mathrm{NPK}+\mathrm{B}_{0}, \mathrm{~B}_{1}$, and $\mathrm{B}_{2}(129.66,119.0$ and 119.0), and $\mathrm{GM}_{3}+100 \% \mathrm{NPK}+\mathrm{B}_{0}, \mathrm{~B}_{1}$, and $\mathrm{B}_{2}$ (128.66, 121.33, and 123.33).

\section{4-Effect of growing media, mineral and bio-fertilization on the main constituents:}

\section{Chlorophyll (a) (mg/100 g f.w.):}

The data listed in Table (30) show that the interaction between growing media and mineral fertilizer levels were significantly increased chlorophyll (a) content in the two seasons. The pronounced value $(7.58 \mathrm{mg} / 100$ g f.w.) was found on the plants treated with $\mathrm{NPK}$ at $50 \%$ on $\mathrm{GM}_{5}$, and $(16.18 \mathrm{mg} / 100 \mathrm{~g}$ f.w.) with treatment $\mathrm{GM}_{3}+100 \%$ NPK in the second season. While a decrease in chlorophyll (a) content (5.07 mg/100 g f.w.) was recorded on the plants fertilized with NPK at $50 \%$ on $\mathrm{GM}_{2}$.

Data obtained in Table (31) show that the interaction between growing media and bio-fertilizers doses were significantly increased chlorophyll (a) content in the two seasons. The highest chlorophyll (a) content (10.17 and $11.45 \mathrm{mg} / 100 \mathrm{~g}$ f.w.) were obtained using $\mathrm{B}_{2}$ on $\mathrm{GM}_{3}$ in the two seasons, respectively. Whereas $\mathrm{GM}_{5}+\mathrm{B}_{0}$ in the first season gave the lowest chlorophyll (a) content (4.16 mg/100 g f.w.), and treatment of $\mathrm{GM}_{1}+\mathrm{B}_{0}$ gave lowest chlorophyll (a) content (3.69 mg/100 g f.w.) in the second season.

Data given in Table (32) show that the most combinations between NPK fertilizer levels and bio-fertilizers doses were significant increased chlorophyll (a) content in the two seasons. The heaviest green color in leaves was presented with treatment $B_{2}$ combined with $50 \%$ and $100 \%$ NPK (8.80 and $13.21 \mathrm{mg} / 100 \mathrm{~g}$ f.w.) in the two seasons, respectively. The pronounced value was obtained by the highest levels of each of biofertilizers doses $\mathrm{B}_{1}$ and $\mathrm{B}_{2}$ (10.31and 13.21 $\mathrm{mg} / 100 \mathrm{~g}$ f.w.) combined with NPK at $100 \%$ of R.D. in the second season.

The data in Table (33) clear that there were significant differences in chlorophyll (a) content from the interaction between 
M.R.A. Hassan et al.

Table 26. Average of number of cormlets of Gladiolus grandiflorus cv. "White Prosperity" plants as affected by the interaction between growing media and mineral fertilizer in seasons of 2010 and 2011.

\begin{tabular}{cccccccc}
\hline $\begin{array}{c}\text { Growing } \\
\text { media }\end{array}$ & $\mathbf{2 0 1 0}$ & $\mathbf{5 0}$ & $\mathbf{2 0 1 1}$ & $\mathbf{2 0 1 0}$ & $\mathbf{2 0 1 1}$ & $\mathbf{2 0 1 0}$ & $\mathbf{1 0 0}$ \\
\hline $\mathbf{G M}_{\mathbf{1}}$ & 65.77 & 69.11 & 85.66 & 86.88 & 94.33 & 92.33 \\
$\mathbf{G M}_{\mathbf{2}}$ & 81.44 & 90.0 & 77.55 & 83.33 & 70.77 & 78.44 \\
$\mathbf{G M}_{\mathbf{3}}$ & 84.55 & 115.55 & 99.22 & 122.55 & 88.55 & 124.44 \\
$\mathbf{G M}_{\mathbf{4}}$ & 66.11 & 91.11 & 71.00 & 91.33 & 72.33 & 79.44 \\
$\mathbf{G M}_{\mathbf{5}}$ & 72.44 & 93.44 & 84.66 & 93.77 & 102.66 & 108.33 \\
L.S.D. & & $2010=5.83$ & & & $2011=13.34$ & \\
\hline
\end{tabular}

L.S.D. $\cdot_{0 \cdot 05}=$ least significant differences at 0.05 of probability.

Table 27. Average of number of cormlets of Gladiolus grandiflorus cv. "White Prosperity" plants as affected by the interaction between growing media and bio-fertilizer in seasons of 2010 and 2011.

\begin{tabular}{cccccccc}
\hline $\begin{array}{c}\text { Growing } \\
\text { media }\end{array}$ & $\mathbf{2 0 1 0}$ & $\mathbf{B}_{\mathbf{0}}$ & $\mathbf{2 0 1 1}$ & $\mathbf{2 0 1 0}$ & $\mathbf{2 0 1 1}$ & $\mathbf{2 0 1 0}$ & $\mathbf{B}_{\mathbf{2}}$ \\
\hline $\mathbf{G M}_{\mathbf{1}}$ & 73.66 & 73.44 & 83.55 & 79.22 & 88.55 & 95.66 \\
$\mathbf{G M}_{\mathbf{2}}$ & 66.77 & 87.77 & 74.00 & 80.77 & 89.00 & 83.22 \\
$\mathbf{G M}_{\mathbf{3}}$ & 82.88 & 120.00 & 87.88 & 123.55 & 101.55 & 119.00 \\
$\mathbf{G M}_{\mathbf{4}}$ & 64.66 & 77.00 & 64.66 & 90.88 & 80.11 & 94.00 \\
$\mathbf{G M}_{\mathbf{5}}$ & 82.66 & 83.44 & 86.22 & 102.22 & 90.88 & 109.88 \\
L.S.D. 0.05 & & $2010=4.60$ & & & $2011=7.46$ & \\
\hline
\end{tabular}

L.S.D. $\cdot_{0 \cdot 05}=$ least significant differences at 0.05 of probability.

Table 28. Average of number of cormlets of Gladiolus grandiflorus cv. "White Prosperity" plants as affected by the interaction between mineral fertilizer and bio-fertilizer in seasons of 2010 and 2011.

\begin{tabular}{cccccccc}
\hline $\begin{array}{c}\text { Mineral } \\
\text { fertilizer } \\
\mathbf{\%}\end{array}$ & $\mathbf{2 0 1 0}$ & $\mathbf{B}_{\mathbf{0}}$ & $\mathbf{2 0 1 1}$ & $\mathbf{2 0 1 0}$ & $\mathbf{2 0 1 1}$ & $\mathbf{2 0 1 0}$ & $\mathbf{2 0 1 1}$ \\
\hline $\mathbf{5 0}$ & 69.06 & 80.40 & 73.06 & 96.13 & 80.06 & 99.00 \\
$\mathbf{7 5}$ & 76.73 & 95.20 & 81.26 & 94.06 & 92.86 & 97.46 \\
$\mathbf{1 0 0}$ & 76.60 & 89.40 & 83.46 & 95.80 & 97.13 & 104.60 \\
L.S.D. $\mathbf{B}_{\mathbf{0} 05}$ & & $2010=3.24$ & & & $2011=5.27$ & \\
\hline
\end{tabular}

L.S.D.0.05 = least significant differences at 0.05 of probability. 
Table 29. Average of number of cormlets of Gladiolus grandiflorus cv. "White Prosperity" plants as affected by the interaction between growing media, mineral fertilizer and bio-fertilizer in seasons of 2010 and 2011.

\begin{tabular}{|c|c|c|c|c|c|c|c|}
\hline \multirow{3}{*}{$\begin{array}{c}\text { Growing } \\
\text { media }\end{array}$} & \multirow{3}{*}{$\begin{array}{c}\text { Mineral } \\
\text { fertilizer } \\
\%\end{array}$} & \multicolumn{6}{|c|}{ Bio-fertilizer } \\
\hline & & & 2010 & & & 2011 & \\
\hline & & $\mathbf{B}_{0}$ & $\mathbf{B}_{1}$ & $\mathbf{B}_{2}$ & $\mathbf{B}_{0}$ & $\mathbf{B}_{1}$ & $\mathbf{B}_{2}$ \\
\hline \multirow{3}{*}{$\mathbf{G M}_{1}$} & 50 & 60.00 & 66.00 & 71.33 & 60.66 & 68.33 & 78.33 \\
\hline & 75 & 78.33 & 89.66 & 89.00 & 94.33 & 79.66 & 86.66 \\
\hline & 100 & 82.66 & 95.00 & 105.33 & 65.33 & 89.66 & 122.00 \\
\hline & 50 & 70.33 & 73.33 & 100.66 & 95.00 & 94.66 & 80.33 \\
\hline \multirow[t]{3}{*}{$\mathbf{G M}_{2}$} & 75 & 56.66 & 75.00 & 101.00 & 93.66 & 71.66 & 84.66 \\
\hline & 100 & 73.33 & 73.66 & 65.33 & 74.66 & 76.00 & 84.66 \\
\hline & 50 & 79.66 & 86.33 & 87.66 & 101.66 & 130.33 & 114.66 \\
\hline \multirow[t]{3}{*}{$\mathbf{G M}_{3}$} & 75 & 97.00 & 93.66 & 107.00 & 129.66 & 119.00 & 119.00 \\
\hline & 100 & 72.00 & 83.66 & 110.00 & 128.66 & 121.33 & 123.33 \\
\hline & 50 & 64.00 & 66.66 & 67.66 & 71.00 & 96.00 & 106.33 \\
\hline \multirow[t]{3}{*}{$\mathbf{G M}_{4}$} & 75 & 68.33 & 63.66 & 81.00 & 82.66 & 93.33 & 98.00 \\
\hline & 100 & 61.66 & 63.66 & 91.66 & 77.33 & 83.33 & 77.66 \\
\hline & 50 & 71.33 & 73.00 & 73.00 & 73.66 & 91.33 & 115.33 \\
\hline \multirow{2}{*}{$\mathbf{G M}_{5}$} & 75 & 83.33 & 84.33 & 86.33 & 75.66 & 106.66 & 99.00 \\
\hline & 100 & 93.33 & 101.33 & 113.33 & 101.00 & 108.66 & 115.33 \\
\hline L.S.D. ${ }_{0.05}$ & & & $2010=7.95$ & & & $2011=12.92$ & \\
\hline
\end{tabular}

L.S.D. $0 \cdot 05=$ least significant differences at 0.05 of probability.

Table 30. Average of chlorophyll (a) content (mg/100 g f.w.) of Gladiolus grandiflorus cv. "White Prosperity" plants as affected by the interaction between growing media, and mineral fertilizer in seasons of 2010 and 2011.

\begin{tabular}{|c|c|c|c|c|c|c|}
\hline \multirow{3}{*}{$\begin{array}{l}\text { Growing } \\
\text { media }\end{array}$} & \multicolumn{6}{|c|}{ Mineral fertilizer \% } \\
\hline & \multicolumn{2}{|c|}{50} & \multicolumn{2}{|c|}{75} & \multicolumn{2}{|c|}{100} \\
\hline & 2010 & 2011 & 2010 & 2011 & 2010 & 2011 \\
\hline $\mathbf{G ~ M}_{1}$ & 6.39 & 1.21 & 5.94 & 4.26 & 6.66 & 9.84 \\
\hline $\mathbf{G M}_{2}$ & 5.07 & 3.10 & 5.98 & 5.73 & 6.31 & 9.21 \\
\hline $\mathbf{G M}_{3}$ & 5.71 & 5.29 & 6.96 & 7.95 & 7.18 & 16.18 \\
\hline $\mathbf{G M}_{4}$ & 6.07 & 4.22 & 7.14 & 7.95 & 6.01 & 6.18 \\
\hline $\mathbf{G M}_{5}$ & 7.58 & 4.22 & 5.90 & 6.49 & 6.22 & 9.30 \\
\hline L.S.D. 0.05 & & $2010=0.87$ & & & $2011=0.6$ & \\
\hline
\end{tabular}

L.S.D. $\cdot_{00}=$ least significant differences at 0.05 of probability.

Table 31. Average of chlorophyll (a) content (mg/100 g f.w.) of Gladiolus grandiflorus cv. "White Prosperity" plants as affected by the interaction between growing media and bio-fertilizer in seasons of 2010 and 2011.

\begin{tabular}{|c|c|c|c|c|c|c|}
\hline \multirow{3}{*}{$\begin{array}{c}\text { Growing } \\
\text { media }\end{array}$} & \multicolumn{6}{|c|}{ Bio-fertilizer } \\
\hline & \multicolumn{2}{|c|}{$\mathbf{B}_{0}$} & \multicolumn{2}{|c|}{$\mathbf{B}_{1}$} & \multicolumn{2}{|c|}{$\mathbf{B}_{2}$} \\
\hline & 2010 & 2011 & 2010 & 2011 & 2010 & 2011 \\
\hline $\mathrm{GM}_{1}$ & 5.30 & 3.69 & 5.99 & 4.67 & 4.20 & 6.86 \\
\hline $\mathbf{G M}_{2}$ & 5.07 & 4.61 & 5.04 & 5.72 & 7.87 & 7.71 \\
\hline $\mathbf{G M}_{3}$ & 6.21 & 8.24 & 7.05 & 9.74 & 10.17 & 11.45 \\
\hline $\mathbf{G M}_{4}$ & 5.33 & 5.48 & 7.27 & 6.61 & 5.78 & 7.91 \\
\hline $\mathbf{G M}_{5}$ & 4.16 & 5.99 & 6.33 & 6.91 & 6.66 & 7.89 \\
\hline L.S.D. 0.05 & & $2010=2.41$ & & & $2011=0.40$ & \\
\hline
\end{tabular}

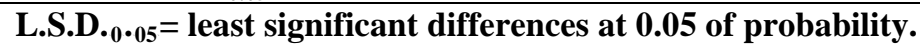


M.R.A. Hassan et al.

Table 32. Average of chlorophyll (a) content (mg/100 g f.w.) of Gladiolus grandiflorus cv."'White Prosperity" plants as affected by the interaction between mineral fertilizer and bio-fertilizer in seasons of 2010 and 2011.

\begin{tabular}{|c|c|c|c|c|c|c|}
\hline \multirow{3}{*}{$\begin{array}{c}\text { Mineral } \\
\text { fertilizer } \\
\%\end{array}$} & \multicolumn{6}{|c|}{ Bio-fertilizer } \\
\hline & & & & & & \\
\hline & 2010 & 2011 & 2010 & 2011 & 2010 & 2011 \\
\hline 50 & 5.68 & 2.51 & 6.12 & 3.90 & 8.80 & 4.83 \\
\hline 75 & 4.42 & 5.57 & 5.99 & 6.15 & 7.13 & 7.05 \\
\hline 100 & 5.54 & 8.73 & 6.90 & 10.31 & 4.88 & 13.21 \\
\hline L.S.D. $_{0.05}$ & & $2010=1.70$ & & & $2011=0.3$ & \\
\hline
\end{tabular}

L.S.D. ${ }_{0 \cdot 05}=$ least significant differences at 0.05 of probability.

Table 33. Average of chlorophyll (a) content (mg/100 g f.w.) of Gladiolus grandiflorus cv."White Prosperity" plants as affected by the interaction between growing media, mineral fertilizer and bio-fertilizer in seasons of 2010 and 2011.

\begin{tabular}{|c|c|c|c|c|c|c|c|}
\hline \multirow{3}{*}{$\begin{array}{c}\text { Growing } \\
\text { Media }\end{array}$} & \multirow{3}{*}{$\begin{array}{c}\text { Mineral } \\
\text { fertilizer } \\
\%\end{array}$} & \multicolumn{6}{|c|}{ Bio-fertilizer } \\
\hline & & \multicolumn{3}{|c|}{2010} & \multicolumn{3}{|c|}{2011} \\
\hline & & $\mathbf{B}_{0}$ & $\mathbf{B}_{1}$ & $\mathbf{B}_{2}$ & $\mathbf{B}_{0}$ & $\mathbf{B}_{1}$ & $\mathbf{B}_{2}$ \\
\hline & 50 & 10.99 & 4.40 & 2.85 & 0.44 & 0.88 & 2.05 \\
\hline \multirow[t]{3}{*}{$\mathbf{G M}_{1}$} & 75 & 0.68 & 3.36 & 6.89 & 3.17 & 4.16 & 5.45 \\
\hline & 100 & 4.23 & 10.20 & 2.86 & 7.46 & 8.97 & 13.08 \\
\hline & 50 & 2.79 & 7.12 & 12.92 & 1.47 & 3.53 & 4.28 \\
\hline \multirow[t]{3}{*}{$\mathbf{G M}_{2}$} & 75 & 5.34 & 3.43 & 6.08 & 4.97 & 5.62 & 6.26 \\
\hline & 100 & 7.09 & 4.57 & 4.61 & 7.39 & 8.00 & 12.24 \\
\hline & 50 & 5.27 & 6.54 & 15.21 & 4.53 & 5.18 & 6.18 \\
\hline \multirow[t]{3}{*}{$\mathbf{G M}_{3}$} & 75 & 5.01 & 8.37 & 10.83 & 7.04 & 7.74 & 9.06 \\
\hline & 100 & 8.35 & 6.24 & 4.47 & 13.15 & 16.29 & 19.10 \\
\hline & 50 & 5.68 & 6.63 & 5.30 & 2.66 & 4.37 & 5.62 \\
\hline \multirow[t]{3}{*}{$\mathbf{G M}_{4}$} & 75 & 5.62 & 6.53 & 6.48 & 6.22 & 6.45 & 6.81 \\
\hline & 100 & 4.70 & 8.64 & 5.57 & 7.57 & 9.01 & 11.31 \\
\hline & 50 & 3.68 & 5.90 & 7.73 & 3.44 & 5.55 & 6.05 \\
\hline \multirow[t]{2}{*}{$\mathbf{G M}_{5}$} & 75 & 5.47 & 8.25 & 5.38 & 6.46 & 6.80 & 7.32 \\
\hline & 100 & 3.34 & 4.85 & 6.88 & 8.08 & 8.40 & 10.30 \\
\hline \multicolumn{2}{|c|}{ L.S.D. ${ }_{0.05}$} & & $2010=4$ & & & $2011=0.70$ & \\
\hline
\end{tabular}

L.S.D. $0 \cdot 05=$ least significant differences at 0.05 of probability.

growing media, NPK fertilizer levels and bio-fertilizer doses in the two seasons. The highest amount of chlorophyll (a) was found on the treatments of $\mathrm{GM}_{3}+50 \% \mathrm{NPK}+\mathrm{B}_{2}$ (15.21 mg/100 g f.w.) and $\mathrm{GM}_{3}+100 \%$ $\mathrm{NPK}+\mathrm{B}_{2}(19.10 \mathrm{mg} / 100 \mathrm{~g}$ f.w.) in the two seasons, respectively.

\section{Chlorophyll (b) (mg/100 g f.w.):}

The data listed in Table (34) show that the interaction between growing media and NPK fertilizer levels were significantly increased chlorophyll (b) content in the two seasons, respectively. The pronounced value (11.73 and $12.65 \mathrm{mg} / 100 \mathrm{~g}$ f.w.) was found on the plants treated with NPK at 50\% and $100 \%$ combined with $\mathrm{GM}_{5}$ and $\mathrm{GM}_{3}$ in the two seasons, respectively. While a decrease in chlorophyll (b) content (8.06 and 6.37 $\mathrm{mg} / 100 \mathrm{~g}$ f.w.) was recorded on the plants fertilized with NPK at $50 \%$ on $\mathrm{GM}_{2}$ and $\mathrm{GM}_{1}$ in the two seasons, respectively.

Data obtained in Table (35) show that the interaction between growing media and bio-fertilizer doses significantly increased chlorophyll (b) content in the two seasons. The highest chlorophyll (b) content (15.26 and $11.60 \mathrm{mg} / 100 \mathrm{~g}$ f.w.) was obtained by 
Table 34. Average of chlorophyll (b) content (mg/100 g f.w.) of Gladiolus grandiflorus plants as affected by the interaction between growing media, and mineral fertilizer in seasons of 2010 and 2011.

\begin{tabular}{|c|c|c|c|c|c|c|}
\hline \multirow{3}{*}{ Growing media } & \multicolumn{6}{|c|}{ Mineral fertilizer \% } \\
\hline & \multicolumn{2}{|c|}{50} & \multicolumn{2}{|c|}{75} & \multicolumn{2}{|c|}{100} \\
\hline & 2010 & 2011 & 2010 & 2011 & 2010 & 2011 \\
\hline $\mathbf{G M}_{1}$ & 10.87 & 6.37 & 9.12 & 10.36 & 10.46 & 12.86 \\
\hline $\mathbf{G M}_{2}$ & 8.06 & 7.38 & 9.55 & 9.09 & 9.95 & 11.32 \\
\hline $\mathbf{G M}_{3}$ & 9.28 & 8.53 & 11.27 & 10.76 & 11.38 & 12.65 \\
\hline $\mathbf{G M}_{4}$ & 9.74 & 6.76 & 11.05 & 10.49 & 8.66 & 12.20 \\
\hline $\mathbf{G M}_{5}$ & 11.73 & 7.56 & 8.68 & 10.48 & 9.79 & 12.14 \\
\hline L.S.D. ${ }_{0.05}$ & & $2010=1.26$ & & & $2011=0.42$ & \\
\hline
\end{tabular}

L.S.D. $0 \cdot 05=$ least significant differences at 0.05 of probability.

Table 35. Average of chlorophyll (b) content (mg/100 g f.w.) of Gladiolus grandiflorus plants as affected by the interaction between growing media and bio fertilizer in season of 2010 and 2011.

\begin{tabular}{|c|c|c|c|c|c|c|}
\hline \multirow{3}{*}{$\begin{array}{c}\text { Growing } \\
\text { Media }\end{array}$} & \multicolumn{6}{|c|}{ Bio-fertilizer } \\
\hline & \multicolumn{2}{|c|}{$\mathbf{B}_{0}$} & \multicolumn{2}{|c|}{$\mathbf{B}_{1}$} & \multicolumn{2}{|c|}{$\mathbf{B}_{2}$} \\
\hline & 2010 & 2011 & 2010 & 2011 & 2010 & 2011 \\
\hline $\mathbf{G M}_{1}$ & 8.60 & 8.36 & 4.51 & 9.98 & 6.89 & 11.26 \\
\hline $\mathbf{G M}_{2}$ & 8.27 & 8.50 & 8.07 & 9.22 & 12.50 & 10.08 \\
\hline $\mathbf{G M}_{3}$ & 8.65 & 9.73 & 93.71 & 10.61 & 15.26 & 11.60 \\
\hline $\mathbf{G M}_{4}$ & 8.02 & 9.01 & 10.89 & 9.56 & 8.94 & 10.88 \\
\hline $\mathbf{G M}_{5}$ & 7.22 & 9.26 & 10.33 & 10.07 & 10.25 & 10.85 \\
\hline L.S.D. ${ }_{0.05}$ & & $2010=3.73$ & & & $2011=0.33$ & \\
\hline
\end{tabular}

L.S.D. $\cdot 0 \cdot 05=$ least significant differences at 0.05 of probability.

using $B_{2}$ on $G_{3}$ in the two seasons, respectively. Whereas, $\mathrm{GM}_{1}+\mathrm{B}_{1}$ in the first season gave the lowest chlorophyll (b) content (4.51 mg/100 g f.w.), and treatment of $\mathrm{GM}_{1}+\mathrm{B}_{0}$ gave the lowest chlorophyll (b) content $(8.36 \mathrm{mg} / 100 \mathrm{~g} \mathrm{f.w.})$ in the second season.

The data in Table (36) show that the interaction between mineral and biofertilizers was significant on chlorophyll (b) content in the second season but nonsignificant differences in the first season. The maximum values of chlorophyll (b) content obtained with the combination of $100 \% \mathrm{NPK}+\mathrm{B}_{2}$ (13.13 mg/100 g f.w.) in the second season.

The data in Table (37) clear that there were a significant differences in chlorophyll (b) content from the interaction between growing media, mineral fertilizer and biofertilizers doses in the two seasons. The highest amount of chlorophyll (b) was found on the treatment of $\mathrm{GM}_{3}+50 \%$ and $100 \%$ $\mathrm{NPK}+\mathrm{B}_{2}$ (22.45 and $13.54 \mathrm{mg} / 100$ g f.w.) in the two seasons, respectively.

\section{DISCUSSION}

\section{Effect of mineral (NPK) fertilization:}

The role of mineral NPK fertilizers in improving different aspects of growth and flowering of gladiolus plants is attributed to the unique physiological roles of such three essential nutrients in plant growth and development (Gamal, 2008).

Obtained data proved that vegetative growth characters, flowering parameters corm and cormels production and chemical constituents of Gladiolus grandiflorus plants were improved by using different mineral NPK fertilization levels. The increment of the previous parameters due to the mineral NPK fertilization treatments could be 
Table 36. Average of chlorophyll (b) content (mg/100 g f.w.) of Gladiolus grandiflorus plants as affected by the interaction between mineral fertilizer and bio fertilizer in seasons of 2010 and 2011.

\begin{tabular}{|c|c|c|c|c|c|c|}
\hline \multirow{3}{*}{$\begin{array}{c}\text { Mineral } \\
\text { fertilizer \% }\end{array}$} & \multicolumn{6}{|c|}{ Bio-fertilizer } \\
\hline & \multicolumn{2}{|c|}{$\mathbf{B}_{0}$} & \multicolumn{2}{|c|}{$\mathrm{B}_{1}$} & \multicolumn{2}{|c|}{$\mathbf{B}_{2}$} \\
\hline & 2010 & 2011 & 2010 & 2011 & 2010 & 2011 \\
\hline 50 & 8.90 & 5.93 & 7.07 & 7.25 & 8.08 & 8.78 \\
\hline 75 & 9.03 & 9.44 & 9.25 & 10.38 & 7.83 & 10.39 \\
\hline 100 & 13.54 & 11.54 & 9.90 & 12.03 & 7.8 .8 & 13.13 \\
\hline L.S.D..$_{0.05}$ & & $2010=$ N.S. & & & $2011=0.26$ & \\
\hline
\end{tabular}

L.S.D. $0 \cdot 05=$ least significant differences at 0.05 of probability.

N.S.= non-significant differences at 0.05 of probability.

Table 37. Average of chlorophyll (b) content (mg/100 g f.w.) of Gladiolus grandiflorus plants as affected by the interaction between growing media, mineral fertilizer and bio-fertilizer in seasons of 2010 and 2011.

\begin{tabular}{|c|c|c|c|c|c|c|c|}
\hline \multirow{3}{*}{$\begin{array}{c}\text { Growing } \\
\text { media }\end{array}$} & \multirow{3}{*}{$\begin{array}{c}\text { Mineral } \\
\text { fertilizer } \\
\%\end{array}$} & \multicolumn{6}{|c|}{ Bio-fertilizer } \\
\hline & & \multicolumn{3}{|c|}{2010} & \multicolumn{3}{|c|}{2011} \\
\hline & & $\mathbf{B}_{0}$ & $\mathbf{B}_{1}$ & $\mathbf{B}_{2}$ & $\mathbf{B}_{0}$ & $\mathbf{B}_{1}$ & $\mathbf{B}_{2}$ \\
\hline \multirow{4}{*}{$\mathbf{G M}_{1}$} & 50 & 15.94 & 5.59 & 5.04 & 3.55 & 6.65 & 8.91 \\
\hline & 75 & 3.54 & 3.36 & 8.64 & 9.50 & 10.76 & 10.81 \\
\hline & 100 & 6.32 & 4.57 & 6.98 & 12.01 & 12.52 & 12.05 \\
\hline & 50 & 5.89 & 11.10 & 20.45 & 6.57 & 7.40 & 8.17 \\
\hline \multirow{3}{*}{$\mathbf{G M}_{2}$} & 75 & 8.18 & 4.69 & 9.63 & 8.53 & 9.16 & 9.59 \\
\hline & 100 & 10.75 & 8.42 & 7.42 & 10.40 & 11.09 & 12.48 \\
\hline & 50 & 6.63 & 9.38 & 22.45 & 7.18 & 8.67 & 9.73 \\
\hline \multirow[t]{3}{*}{$\mathbf{G M}_{3}$} & 75 & 7.01 & 12.46 & 12.95 & 10.11 & 10.65 & 11.52 \\
\hline & 100 & 12.30 & 7.30 & 10.38 & 11.89 & 12.52 & 13.54 \\
\hline & 50 & 9.05 & 9.80 & 8.53 & 5.50 & 6.10 & 8.68 \\
\hline \multirow[t]{3}{*}{$\mathbf{G M}_{4}$} & 75 & 8.38 & 10.00 & 10.41 & 9.95 & 10.56 & 10.97 \\
\hline & 100 & 6.63 & 12.86 & 7.90 & 12.59 & 12.03 & 12.98 \\
\hline & 50 & 7.00 & 9.27 & 11.23 & 6.83 & 7.45 & 8.41 \\
\hline \multirow[t]{2}{*}{$\mathbf{G M}_{5}$} & 75 & 8.27 & 15.75 & 7.88 & 9.13 & 10.76 & 11.54 \\
\hline & 100 & 6.40 & 5.99 & 11.65 & 11.83 & 12.0 & 12.60 \\
\hline \multicolumn{2}{|c|}{ L.S.D. 005} & & $2010=$ & & & $2011=0$. & \\
\hline
\end{tabular}

L.S.D.0.05 = least significant differences at 0.05 of probability.

explained in the light of the biological and physiological roles of the three macro elements, $\mathrm{N}, \mathrm{P}$ and $\mathrm{K}$ on vegetative growth parameters, and chemical constituents as reported by (Mohamed, 2011).

Nitrogen is an essential nutrient as a constituent of different organic compound which are very important for plant growth. It is essential for protein formation and it is built into the body of all simple and conjugated protein and forms part of nucleic acids (DNA and RNA) that are major constituents of plant cell cytoplasm. This macro element is present in different organic compounds, i.e. amino acid, many enzymes, purines phosphatides, many energy transfer compounds (ADP and ATP) chlorophylls, pigments, vitamins, alkaloids, as well as other organic substances of plant cell and protoplasm. Therefore, nitrogen was found to promote the number and the size of plant cells that reflected, consequently, on augmenting vegetative growth production via stimulation of leaf production, plant height and root system. Also the levels of endogenous hormones were found to respond to nitrogen, therefore the content of free auxin and GA-like substances were 
decreased and growth inhibiting substances were increased due to the deficiency of nitrogen. Moreover, the plant cannot carry on its life processes if it lacks nitrogen to form all aforementioned vital constituents. Nitrogen deficiency is accompanied by failure to synthesize normal amounts of chlorophylls, which affect directly the photosynthetic process and carbohydrates process. It cannot go on the production of protein, nucleic acids unless $\mathrm{N}$ is available.

Phosphorus is essential for cell division and meristem tissue development and that could be attributed to the fact that it is one of cell nucleus components i.e. nucleic acids, phytin and phospholipids and cell cannot be divided unless there is adequate phosphorus to form the extra nucleus. Therefore, phosphorus tends to be concentrated in the growing points of the plant. Phosphorus in cell becomes united with carbon, oxygen, nitrogen, hydrogen and other elements to form complex organic molecules. Phosphorus is involved in the processes of phosphorylation, which cause production of higher energy compounds (ADP and ATP) responsible for most of the changes in the life processes. In addition, phosphorus has fundamental roles in different enzymatic reaction. Moreover, phosphate compounds are essential and important for many physiological processes namely, photosynthesis, inter conversion of carbohydrates and related glycolsis, metabolism of amino acids and fat and biological oxidation. Also, phosphorus is a constituent of the coenzymes NAD and NADP, which are the very important materials of two physiological processes i.e. photosynthesis and respiration in the plants.

Potassium is macronutrient which is present in the form of organic and inorganic salts, but it does not form an integral part of the structure of any known organic compound in the plants. It appears to serve rather as a metabolic regulator or catalyst. Potassium is essential for different physiological processes such as nitrogen metabolism and protein synthesis, various enzymes activation and promotion of the meristematic tissue growth. It aids in the uptake of other nutrients and in their movement within the plant. In addition, the presence of potassium and other ions in the solution helps to maintain the osmotic concentration necessary to cell turgid, which is essential for adjustment of stomatal movement and water relations. Moreover, potassium is necessary for the metabolism of carbohydrates via its influence on photosynthesis process and plays an important role in translocation of carbohydrates from the plant leaves to the roots.

The data of the experimental seasons of the present investigation indicate that increasing NPK of mineral fertilizer at 50\% and $75 \%$ NPK of recommended doses led to increase almost growth (plant height, number of leaves, leaf fresh weight, leaf dry weight and leaf area) and flowering (i.e. spike fresh weight, spike dry weight, flower diameter, number of florets/plant, and spike length). The corm parameters (corm volume $\left(\mathrm{cm}^{3}\right.$ ), corm dry weight and number of cormlets/plant) increased by increasing the NPK fertilizer levels to $100 \%$ of recommended dose.

The favorable effect of nitrogen in promoting number and length of leaves might be due to the fact that nitrogen is a constituent part of protein and component of protoplasm which increases the chlorophyll contents in leaves. All this factors led to cell multiplication, cell enlargement and cell differentiation which have resulted in increasing of number and length of leaves (Parmer, 2007).

The quality and production of cut flowers is primarily a varietal trait, it is greatly influenced by climatic, geographical and nutritional factors. Out of them, nutritional factor is playing a major role. At present, nutrients are supplied through chemical fertilizers. The use of organic manures and biofertilizer along with judicious use of chemical fertilizers is nothing but balancing the diet of crop and 
soil. It improves physico-chemical and biological properties of soil, besides improving the efficiency of applied nutrients. (Pansuriya and Chauhan 2015).

\section{Effect of bio-fertilization:}

Obtained data in the present study show beneficial positive effect of $\mathrm{N}$-fixing bacteria and phosphate solublizing bacteria on different growth aspects, yield components and chemical composition of gladiolus plants. These enhancing influences of biofertilizers might be attributed to the following physiological roles of such three substances.

\section{1- Effect of $\mathrm{N}$-fixing bacteria:}

Application of nitrobein (fertilizer containing different strains of $\mathrm{N}$-fixing bacteria to gladiolus plants in this study led to improvement of vegetative growth, flowering, and corm production. many investigators explained the role of $\mathrm{N}$-fixing bacteria such as Hauka (2000), who suggested the roles of $\mathrm{N}$-fixing bacteria in:

1. Fixation of the atmospheric $\mathrm{N}$, which cause an increment of available $\mathrm{N}$ consequently increasing the formation of metabolites.

2. N-fixing bacteria produce adequate amounts of phytohormons such as indole acetic acid (IAA). gibberellins and cytokines. These phytohormons cause.

a- Increase of the surface area unit of root length.

b- Hair branching with an increment in soil $\mathrm{N}$ available.

c- Promotion of plant growth, absorption of different nutrients and photosynthesis process (Hegde et al., 1999).

3. N-fixing bacteria produce organic acids such as amino acids, namely aspartate, glutamate, serine and glutamate. (Hartmann, 1989).
4. N-fixing bacteria enhanced the uptake of different nutrients and improve water status. (Hegde et al., 1999).

5. N-fixing bacteria protect their host plants against plant pathogens through production of antibacterial and antifungal substances.

6. In the end $\mathrm{N}$-fixing bacteria, in general, positively affect their host plants through one or more mechanism i.e. N-fixation, producing of growth promoting substances or organic acids, enhancing the uptake of different nutrients or protecting the plants against plant pathogens. (Hauka, 2000).

\section{2- Effect of Phosphate Solublizing Bacteria PSB:}

Posphorien is recognized as a biofertilizer product containing very active phosphate solublizing bacteria. So, it could be used to enhance the solubility of phosphorus and to facilate the uptake of phosphorus by plant. Moreover, such biofertilizer product plays an important role in the development of many plant species including medicinal and aromatic plants by supplying growing plants with available forms of phosphorus and by its capability of producing organic and inorganic acids and $\mathrm{CO}_{2}$. (Mohamed, 2011).

Our results are in agreement with those obtained by Subba-Rao et al. (1993) and ElKhawaga and Maklad (2013).

On the contrary, El-Haddad et al. (1993) noticed that Azotobacter as a biofertilizer increased nitrogen fixation and promoting some growth substances, organic acid and enhanced nutrient uptake. Furthermore, Abdo (2008) found that increasing N-rate resulted in an obvious increase in leaf area surface associated with higher $\mathrm{N}$-rate compared with the lower one. Meanwhile, the role of Biogen might be attributed to the increase in soil available nitrogen as a result of fixing the atmospheric nitrogen, synthesizing stimulatory compounds i.e. gibberellins, cytokinins and IAA, stimulating photosynthesis, producing different amino 
acids like glutamate, aspartate, histidine and serine and/or improving water status, (Mostafa and Omar, 1993 and El-Haddad et al. (1993). On the other hand, it was found that Phosphorein enhances the availability and solubility of phosphorus through the release of organic and inorganic acids and $\mathrm{CO}_{2}$, produced various growth hormones and increasing the available phosphorus in plant tissues (Follet et al., 1981). Some other investigators pointed out the role of biofertilizers, separately or in combination with mineral fertilization, such as Kathiresan et al. (2002), Mohamed et al. (2006) and Gamal (2008) on gladiolus.

These finding could be related to the important role of microorganism such as nitrogen fixing bacteria, (NFB) Azotobacter or phosphate solubilizing bacteria (PSB) Bacillus megaterium and potassium solubilizing bacteria (KSB) B. circulans, on improving the microbiological activity in the rhizosphere or contributed and solubilize essential minerals, making scarce nutrients more available to the plant. Moreover, production of growth promoting substances or organic acids, that could lead to a stimulate several physiological changes giving a better growth and to the plant more tolerance to stresses (El-Khawaga and Maklad, 2013).

\section{Effect of different growing media:}

Same specie or even the same variety gives different results to different growing media. It is due to difference in the physical and chemical properties of the media which are very important for the growth and development of plant. So to get the ideal growing media different mixtures with different physical and chemical properties are used. Different constituents have different properties like silt, sand, perlite, vermiculite and sphagnum moss allow leaching while clay soil allow water passage slowly. Poultry manure is a rich source of nitrogen while mushroom compost is rich in phosphorus (Larson, 1980).
The size of soil particle also affects plant growth i.e. big soil particles could be one of the hindrances to prevent better root and ultimately plant growth, while the small soil particles can be easily displaced by roots causing better root growth (Kambooh, 1984).

The growing media should be of good quality. It should be well drained to provide proper root aeration and avoid water logging. It should be able of proper nutrient and water retention (Jacob et al., 2009). The amount of carbon nitrogen ratio is the key indicator of nitrogen availability for plant growth. Similar findings were also founded by ElNaggar and El-Nasharty (2009) who observed more leaf length in composted leaves media than in clay media.

The results are also in similarities with the findings of (Tahir et al., 2011) who observed quick emergence of freesia in mushroom compost media.

The production of ornamental pot plants involves a number of cultural inputs, among these, perhaps the most important is the type of growing medium used. The composition of a growing medium should be well drained. Low in soluble salts, with an adequate exchange capacity. Since, innumerable amendment combinations can produce a growing medium with these characteristics, it is important to consider the economic, cultural optimums, transportation, labor and handling. It can be said that sand, clay, peat moss, perlite, vermiculite and organic matter are the basic components of the special medium of planting (Hartmann et al., 2002). Clay has a relatively high cation exchange and water holding capacity. Sand is the least expensive and the heaviest of all inorganic amendments. Peat moss is the most desirable organic matter for the preparation of growing media and is the most widely used substrate for potted plant production in nurseries and it accounts for a significant portion of the material used to grow potted plants (Ribeiro et al., 2007). 


\section{REFERENCES}

Abdo, Z.A.A. (2008). Effect of Some Biofertilization Treatments on Growth and Fruiting of Balady Mandarin Trees. Ph.D. Thesis, Faculty of Agriculture, Minia University, Egypt.

Bashan, Y. and Levanony, H. (1990). Current status of Azospirillum inoculation Technology: Azospirillium as a Challenge for Agriculture. Can. J. Microbiol., 36:591-601.

Doaa, M.R. (2000). Physiological Studies on Some Flowers Pre-treatments of Gladiolus Corms to Produce Commercial Yield. M.Sc. Thesis., Fac. Agric., Alex. Univ., Egypt.

El-Haddad, M.E.; Ishac, Y.Z. and Mostafa, M.I. (1993). The role of biofertilizers in reducing agricultural costs, decreasing environmental pollution and raising crop yield. J. Agric. Sci., Ain Shams Univ., 1:147-159.

El-Khawaga, A.S. and Maklad, M.F. (2013). Effect of combination between bio and chemical fertilization on vegetative growth, yield and quality of Valencia orange fruits. Hortscience Journal of Suez Canal University, 1:269-279

El-Naggar, A.H. and El-Nasharty, A.B. (2009). Effect of growing media and mineral fertilization on growth, flowering, bulbs productivity and chemical constituents of Hippeastrum vittatum, Herb. Amer. Eurasian J. Agric. and Environ. Sci., 6(3):360-371.

Follet, R.H.; Murphy, L.S. and Dorahue, R.L. (1981). Fertilization and soil amendments. Pretice Hall Inc. Inglewood, Cliffs, New Jersey U.S.A.

Gamal, E.A. (2008). Partial replacement of mineral NPK fertilizers by the use of biofertilizers in gladiolus production. Minia J. of Agric. Res. and Develop., 28(2):235-244.

Hartmann, A. (1989). Ecological aspects of growth and nitrogen fixation with
Azospirillum (C.F. Nitrogen fixation with Non-legumes by Shinner et al., 123136, Kluwer Acad. Publ., Dordrecht, Netherlands.

Hartmann, H.T.; Kester, D.E.; Davies, F.T. and Geneve, R.L. (2002). Plant Propagation Principles and Practices. Prentice Hall, Upper Saddle River, New Jersey, USA.

Hauka, F.I. (2000). Effect of using single and composite inoculation with Azospirllium brasilense, Bacillus megatherium var. Phosphaticum and Glomus marcocarpus for improving growth of Zea mays, L. J. Agric. Sci., Mansoura, 25(4):2327-2338.

Hegde, D.M.; Dwivedi, B.S. and Sudhakara, B.S. (1999). Biofertilizers for cereal production in india-A review. Indian $\mathrm{J}$. Agric. Res., 69(2):73-83.

Hogan, L. Elizabeth (1990). Sunset Bulbs for all seasons. Lane publishing Co. Menlo Park, California.

Jacobs, D.F.; Landis, L. and Tara, A. (2009). Nursery manual for native plants: A guide for tribal nurseries. 1:77-93.

Kambooh, C.M. (1984). "Desi khadeen" Zarat Nama., 23 (24):9-28.

Kathiresan, C.; Venkatesha, J.; Misra, R.L. and Sanyta, M. (2002). Effect of biofertilizers with levels of $\mathrm{N}$ and $\mathrm{P}$ on gladiolus. Proc. Nat. Symp. on Indian Floric., 25-27.

Larson, E.L. (1980). Introduction to floriculture. Academic press London. New York.

Mohamed, A.M.H. (2011). Effect of Chemical, Organic and Biofertilization Treatments on Moghat (Glossostemon bruguieri, Desf.) Plants. Ph.D. Thesis., Fac. Agric., Minia Univ., Egypt.

Mohamed, M.A.; Badran, F.S.; Meseha, A.M. and Hasssan, Z.B. (2006). Effect of some fertilizer sources on Gladiolus grandiflorus, L. Plants. I. Effect of P source and P-dissolving microorganisms. 
Third Egyptian-Syrain Conf., 3(1):109118.

Moran, R. and Porath, D. (1980). Chlorophyll determination in intact tissues using NN-dimethyl formamid. Plant physiology., 65:478-479.

Mostafa, S.S. and Omar, M.N. (1993). Estimation of $\mathrm{N}_{2}$ fixed by some diazotrophs in tomato plant using $\mathrm{N}^{15}$ dilution technique. Assiut J. Agric. Sci., 24(1):74-96.

Pansuriya, P.B. and Chauhan, R.V. (2015). Effect of integrated nutrient management on growth, yield and quality of gladiolus (Gladiolus grandiflorus, L.) cV. Psittacinus Hybrid. J. Horticulture, 2:128.

Parmer, Y.S. (2007). Effect of nitrogen, phosphorus and biofertilizer application on plant growth and bulb production in tuberose. Haryana J. Hort. Sci., 36(1\&2):82-85.

Partiquin, D.G.; Doberiener, J. and Jain, D. K. (1983). Sites and processes of Association between diazotrophs and grasses. Can. J. Microbiol., 29:900-915.

Ribeiro, H.M.; Romero, A.M.; Pereira, H.; Borges, P.; Cabral, F. and Vaconcelos, E.
(2007). Evaluation of a compost obtained from forestry wastes and solid phase of pig slurry as a substrate for seedlings production. Bioresource Technology, 98:3294-3297.

Samira, S.A. and El-Tayeb, H.F. (2008). A comparative study for the effect of chemical and biofertilizers on growth, flowering, bulb productivity and chemical composition of Iris tingitana cv. Wedgwood plant. Alex. J. Agri. Res., 53(2):63-70.

Snedecor, G. and Cochran W. (1974). Statistical Methods. Sixth Edition. Iowa State Univ. Presss. Ames. Iowa, USA.

Subba-Rao, N.S., Venkateraman, G.S. and Kannaiyan, S. (1993). Biological Nitrogen Fixation. Indian Council Agric. Res. (ICAR), New Delhi, India, pp:112.

Tahir, A.; Khattak, A.M.; Amin, N.U. and Khan, M.A. (2011). Response of freesia cultivars to different growing media under Peshawar conditions. Sarhad J. Agric., 27(1):43-49.

\section{تأثير التسميد المعدني والحيوي وبيئات النمو على النمو الخضري والزهري وإنتاج الكورمات في نبات

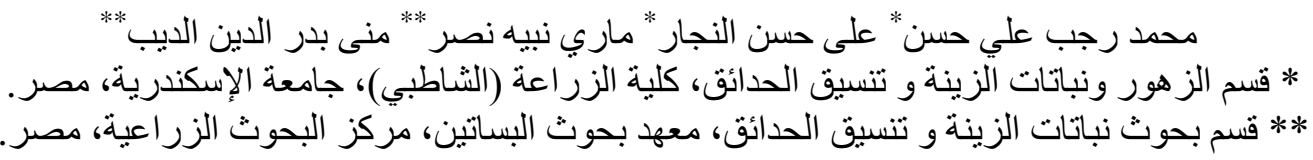

أجريت هذه الدر اسة بمشتل قسم الزهور ونباتات الزينة وتتسيق الحدائق كلية الزر اعة جامعة الإسكندرية وكان الهدف من

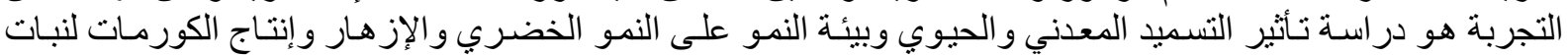

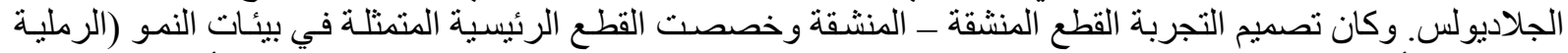

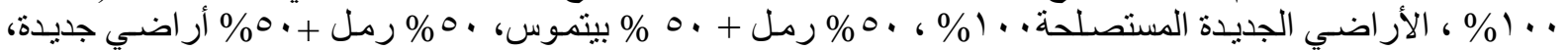

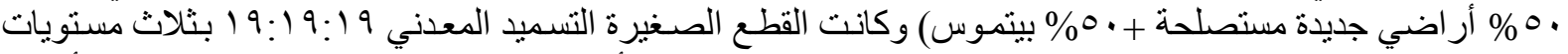

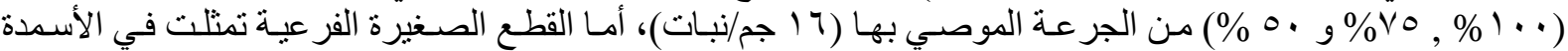

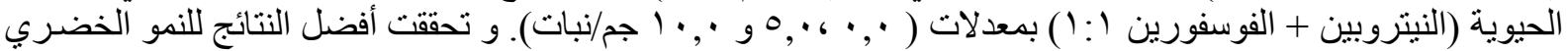

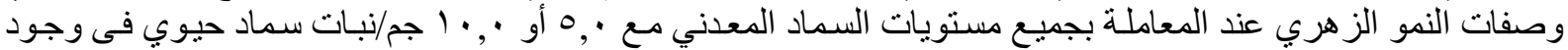

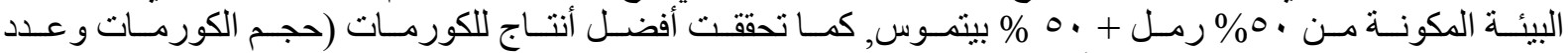

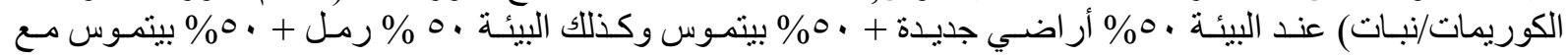




\section{M.R.A. Hassan et al.}

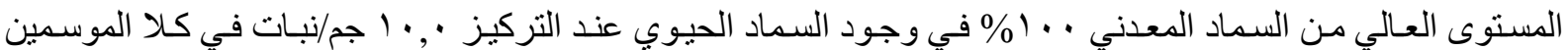

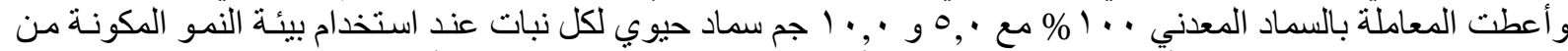
•\% رمل + •0 \% بيتموس أعلى القيم في محتوى الأور اق الطازجة من الكلوروفيل ( أو ب ) . 

